\section{Attempted Endoscopic En Bloc Resection of Mucosal and Submucosal Tumors Using Insulated-Tip Knives: A Pilot Series (including videos)}

\author{
T. Rösch ${ }^{1}$ \\ M. Sarbia ${ }^{1}$ \\ B. Schumacher ${ }^{2}$ \\ K. Deinert ${ }^{2}$ \\ E. Frimberger ${ }^{1}$ \\ T. Toermer ${ }^{1}$ \\ M. Stolte ${ }^{3}$ \\ H. Neuhaus ${ }^{2}$
}

Background and Study Aims: Endoscopic mucosal resection (EMR) of early gastrointestinal cancers has been shown to be effective in treating mucosal malignancies, but en bloc resection (where the entire tumor is removed in one piece) is often not achieved using conventional cap EMR. Other techniques, developed in Japan, include the application of different types of knife such as the insulated-tip instrument. We report our preliminary experience of the use of this knife, in conjunction with other techniques, in attempting en bloc resection of early mucosal cancers and adenomas and in the removal of submucosal tumors (SMTs) of the upper gastrointestinal tract. Patients and Methods: A total of 37 patients (26 men, 11 women, age range 5386) were included in the study; 23 patients had 24 mucosal lesions amenable to EMR, and 14 patients had SMTs shown on endosonography to spare the muscularis propria. Lesions were located in the esophagus $(n=13)$, the stomach $(n=24)$, and the duodenum ( $n=1) ; 40 \%$ of the mucosal lesions were $20 \mathrm{~mm}$ or larger (mean size $18 \mathrm{~mm}$ ), whereas the mean size of the submucosal lesions was $23 \mathrm{~mm}$. After submucosal saline injection, circumcision and dissection of the mucosal lesions was attempted with the aim of achieving en bloc resection. For SMTs, cap mu- cosectomy of the overlying mucosa was done first, and the tumors were then freed using saline injection, and finally resected using snare polypectomy. Results: The strict aim of the study, i.e. complete tumor removal in a single piece, was achieved in only $25 \%$ of the mucosal lesions (some failures were due to unrecognized submucosal infiltration) and $36 \%$ of the SMTs. When a more liberal definition of success was assumed, this rate increased to $65 \%$ for mucosal lesions (piecemeal, no tumor found at surgery or follow-up endoscopy with biopsy) and 79\% for SMTs (piecemeal). No severe complications necessitating surgery or leading to major morbidity occurred. However, clinically significant complications were found in six patients (minor perforation managed conservatively $(n=1)$, severe pain without perforation $(n=1)$, bleeding requiring reintervention $(n=3)$, and aspiration $(n=1))$. Conclusions: Although we are convinced that methods of achieving en bloc resection of mucosal cancers and SMTs must be pursued, the insulated-tip knife in conjunction with conventional endoscopes still has limitations. Innovative endoscope design (double-channel scopes) as well as the development of new accessories will help to overcome the current limitations and further promote endoscopic tumor resection.

\section{Introduction}

Endoscopic mucosal resection (EMR) has been established as a means of effectively treating early cancers of the upper gastrointestinal tract which are limited to the mucosa and fulfil some other criteria such as high differentiation, size up to $2 \mathrm{~cm}$, and absence of ulceration [1-4]. The most commonly used EMR technique is the so-called "cap" method with prior submucosal saline injection. In the literature, which mostly comes from Japan [1] but also includes Western publications [5,6], achievement of

Institution

${ }^{1}$ Department of Internal Medicine II and Pathology, Technical University of Munich, Munich, Germany

${ }^{2}$ Department of Medicine, Evangelisches Krankenhaus, Düsseldorf, Germany

${ }^{3}$ Department of Pathology, Municipal Hospital Bayreuth, Germany

Corresponding Author's present address

T. Rösch, M.D. · Charité · Universitätsmedizin Berlin · Campus Virchow Klinikum • Medizinische Klinik m.S. Hepatologie und Gastroenterologie · Zentrale Interdisciplinäre EndoskopieAugustenburger Platz 1 . 13535 Berlin ·Germany · Fax: +49-30-450-553902E-mail: thomas.roesch@charite.de

Submitted 20 April $2004 \cdot$ Accepted 20 April 2004

Bibliography

Endoscopy 2004; 36 (9): 788-801 @ Georg Thieme Verlag KG Stuttgart · New York · ISSN 0013-726X

DOI 10.1055/s-2004-825838 
en bloc resection (entire tumor removed as a single piece) of these early cancers is reported in only $40-70 \%$ of cases; the remaining lesions are removed in piecemeal fashion, in which case the reliable assessment of whether lateral margins are tumorfree is difficult. If only piecemeal removal of tumors is achievable, this does not comply with the general oncologic principle of complete resection in one piece with sufficient safety margins. Furthermore, it has also been shown that piecemeal resection of early cancers may lead to a higher rate of local tumor recurrence [7]. In an attempt to overcome these limitations of cap EMR, submucosal dissection techniques using a variety of knives, such as the insulated-tip or the triangle-tip models, as well as other modifications, have been developed in Japan [8-11]. Western experience with these techniques is virtually absent. We therefore present our combined pilot experience of using the insulated-tip knife to attempt en bloc mucosal resection of a variety of esophageal and gastric mucosal lesions.

In addition, we also used the insulated-tip knife in a new enucleation technique for submucosal tumors (SMTs) in the esophagus and stomach. Following cap mucosectomy of the overlying mucosa, the tumors are enucleated with the help of saline injection followed by preparation with the insulated-tip knife and finally snare resection.

This report of a pilot series mainly focuses on the technical aspects and the immediate results (i.e., complete tumor removal in one piece), rather than on the long-term outcomes of these new techniques.

\section{Patients and Methods}

In 2003 and the first 2 months of 2004, all patients with mucosal lesions (invasive carcinomas and intraepithelial neoplasms) and SMTs in the esophagus and stomach, which were treated with insulated-tip knives in conjunction with other EMR techniques, at two centers, were included in the study. These comprised $28 \mathrm{pa}-$ tients at center $\mathrm{A}$ and nine at center $\mathrm{B}$. The patients and lesions were selected nonsystematically depending on the availability of knives and participating experienced endoscopists, since this was considered to be a pilot trial of technical feasibility. Naturally, larger mucosal lesions, not expected to be completely resectable by conventional cap EMR, were selected.

The indications for endoscopic in contrast to surgical resection were discussed with both surgeons and patients, and in most cases inoperability or lesion characteristics favored an attempt at endoscopic resection. All patients gave their informed consent to this resection procedure. Endoscopic ultrasound (EUS) was done as an obligatory examination for submucosal lesions to exclude involvement of the muscular layer. However, EUS was optional prior to resection of the mucosal lesions.

Resection of mucosal lesions was done according to previously published experience $[8,9,12]$. First, circumferential marking around the lesion was carried out using electric current and a snare, with a presumed safety margin of $5-10 \mathrm{~mm}$, after indigo carmine dye staining. Then physiological saline was injected into the lesion, starting with the markings, and one or two small

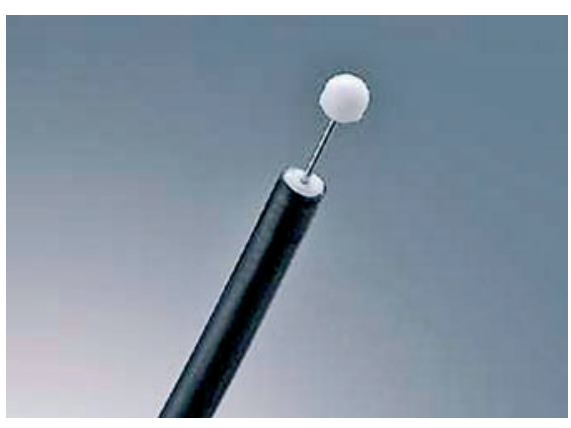

Figure 1 The insulated-tip knife used in the study (see text for details). The insulated ceramic ball at the tip prevents injury to deeper layers; cutting is done with the wire below the white ball at the tip.

openings were created in the mucosa using a conventional needle knife. The insulated-tip knife (Olympus, Tokyo, Japan) (Figure $\mathbf{1}$ ) was then used to circumcise the lesion and afterwards to free it stepwise from the underlying muscularis propria, with the help of repeated saline injections between the submucosa and muscularis propria (with 1:100 000 epinephrine solution also in occasional patients with a tendency to bleeding). The specimen was then either completely resected using the insulatedtip knife, or finally removed using a conventional polypectomy snare if it was attached only to a pedicle. The aim was to obtain the specimen as a single piece (Figure $\mathbf{2}$ ). When visible, small residual fragments of tissue at the margins or in the depth of the resection area were then removed by snare or biopsy forceps and harvested. At center A, all procedures were done with an EMR cap attached to the endoscope tip, as this was felt to be helpful for targeting and preparation of the specimen. Other endoscopes (double-channel, side-viewing) were also occasionally tried at the discretion of the endoscopist. Bleeding during the procedure was managed by injection of epinephrine $(1: 10000)$ and clipping. Similarly to surgical procedures, bleeding occurring during the procedure was recorded but was not regarded as a significant complication if it could be stopped by conventional means (e.g. injection or clipping).

On the basis of experience with the initial preparation steps, the EMR procedure described above was slightly changed at center A during the series. To guarantee a reliable initiation for insulatedtip knife circumcision at the muscular layer (instead of cutting through the submucosa), two or three conventional cap mucosectomies were made at and outside the marking lines, and cutting with the insulated-tip knife was then begun from there (Figure 3 ). The rest of the procedure was carried out as described above. The aim was still to include the entire mucosal lesion within this final resection specimen with adequate safety margins of at least $2-3 \mathrm{~mm}$.

Resection/enucleation of submucosal tumors (SMTs) was only attempted if the presumptive EUS diagnosis was not cyst or lipoma (with one exception, see Table $\mathbf{1}$ for details). Furthermore, the EUS had to clearly show the origin of the SMT in the deep mucosa and/or submucosa, with the underlying muscularis propria intact. The procedure began with two to four conventional cap mucosectomies of the overlying mucosa. The SMT was then separated from the underlying muscularis propria by means of cap suction and preparation with the insulated-tip knife, again with the help of saline injection between the tumor and the underlying muscularis layer. The SMT was either completely enucleated by suction and insulated-tip knife dissection or finally snared and 


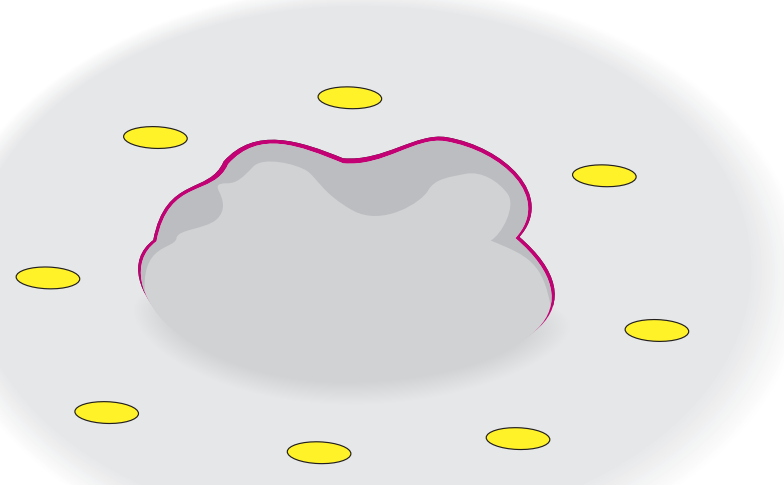

a

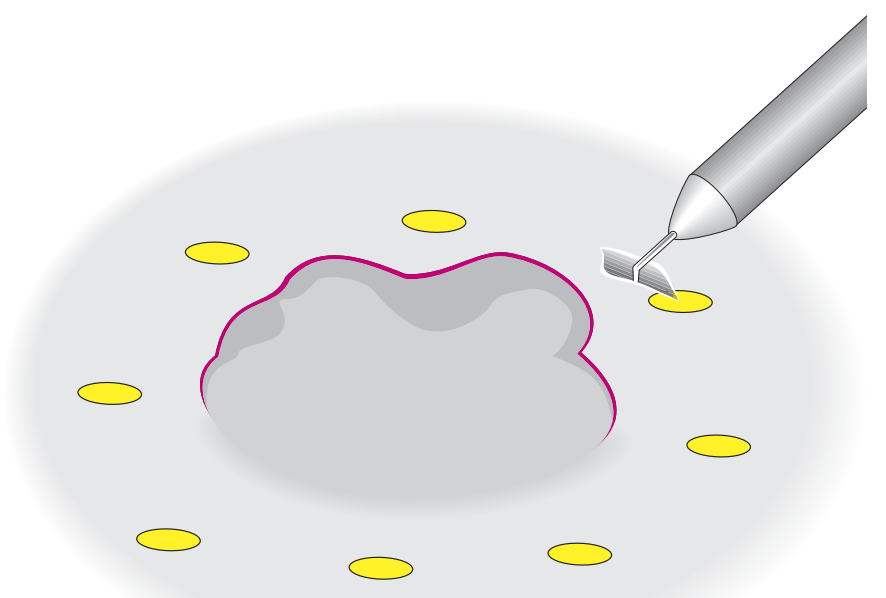

b

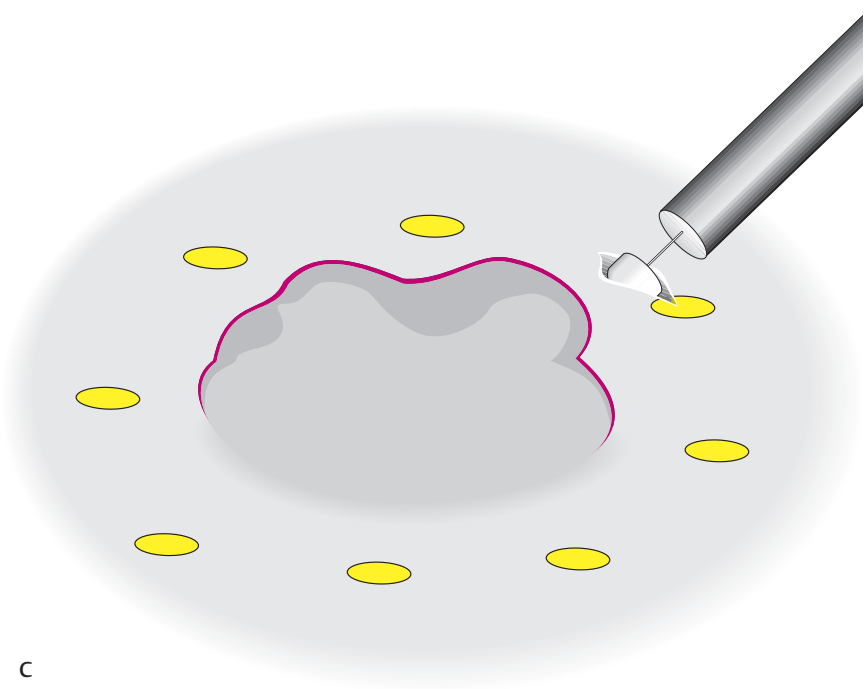

resected conventionally in the case of a small tissue bridge between the tumor and the underlying muscularis (Figure 4). Bleeding was again managed by injection of epinephrine $(1: 10000)$ and clipping. The aim was complete removal of the SMT in one piece.

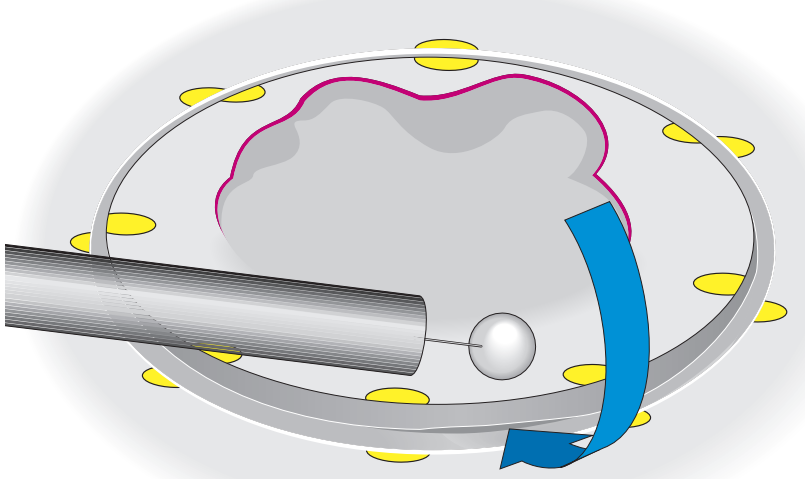

d

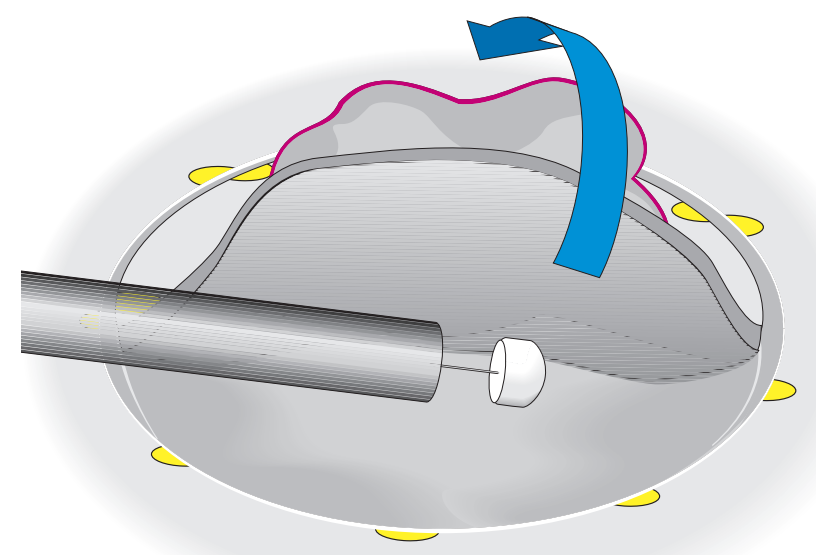

e

Figure 2 Schematic representation of steps in the large-area mucosectomy procedure for mucosal lesions using the insulated-tip knife, described in detail in the text. a Markings. $\mathbf{b}$ Incision with a needleknife after saline injection. c, $\mathbf{d}$ Circumferential incision with the insulated-tip knife. e Separation of the resected piece from the underlying tissue, mostly muscularis propria.

Significant complications were defined as perforations (independent of management) or bleeding requiring re-intervention and/ or transfusions.

\section{Histopathological Evaluation of Specimens}

All EMR specimens were pinned onto cork plates and fixed in $4 \%$ formalin. Macroscopic evaluation included determination of the size of the specimens. In addition, the size of the polypoid mucosal lesions and the submucosal lesions was measured. The size of flat mucosal tumors was determined by measuring the tumor extension on the microscopy slides. Subsequently, the specimens were cut into 4-mm slices and completely embedded in paraffin. The histological examination was carried out by two senior pathologists with a special interest in gastrointestinal pathology (M.Sa., center A; M.St., center B). The neoplastic lesions were histologically typed and graded according to the current World Health Organization (WHO) classification [13]. Tumor typing was based on hematoxylin and eosin (H\&E)-stained slides in most cases. Immunohistochemical investigations were done for 

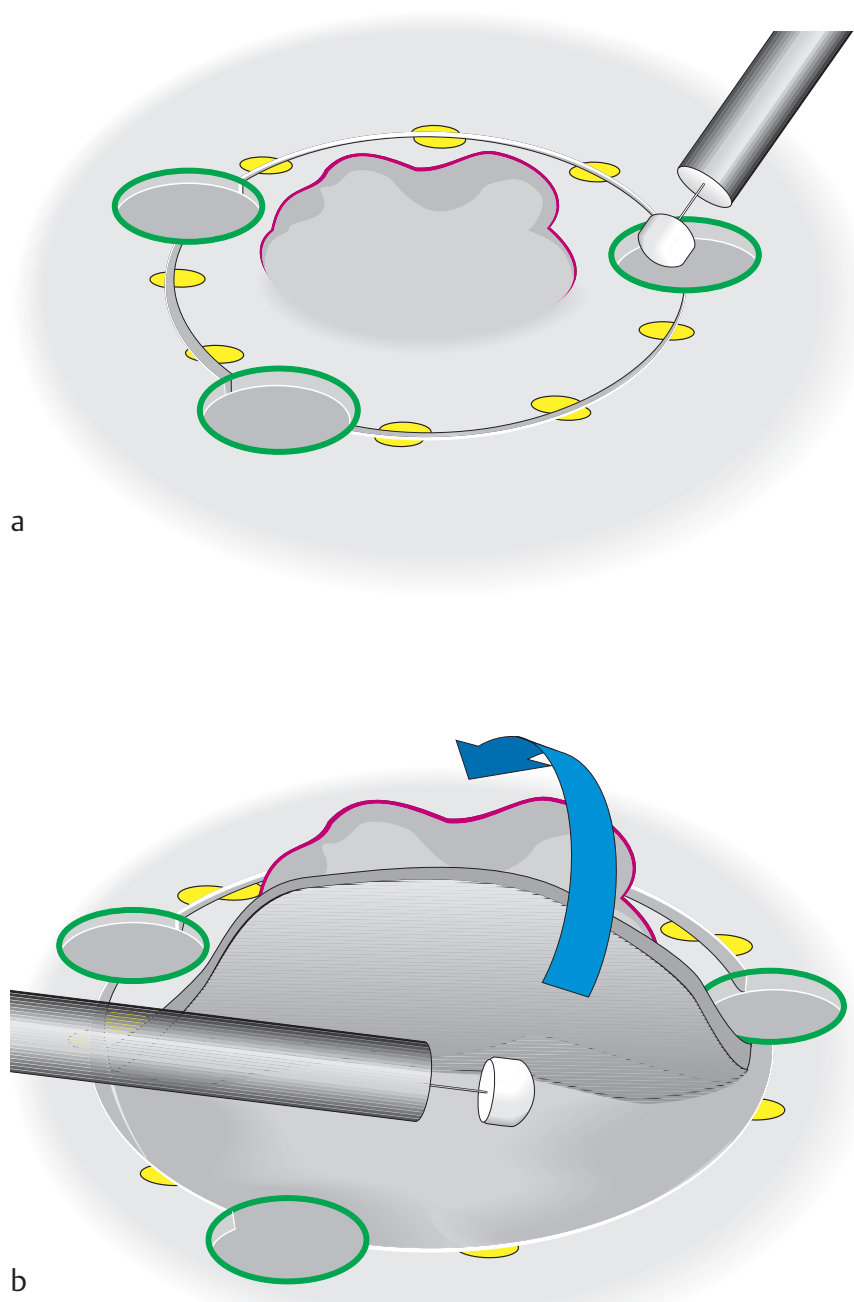

Figure 3 Schematic representation of the steps in the modified largearea mucosectomy procedure for mucosal lesions, with initial circumferential cap mucosectomies and then use of the insulated-tip knife, as described in detail in the text. a The lesion is marked and three cap mucosectomies are done around the markings (green circles). Circumcision with the insulated-tip knife is then carried out between these mucosectomies. b The tissues are separated as shown.

only a subset of submucosal soft tissue tumors. Resection of tumors was considered to be complete (R0) when the neoplastic tissue was circumferentially surrounded by mucosal and submucosal non-neoplastic tissue. Resection was considered to be incomplete (R1) when neoplastic tissue was present at the mucosal and/or submucosal margins of an EMR specimen and no additional resections at the periphery of tumor had been taken that showed tumor-free margins at histological examination. Completeness of resection was considered indeterminable ( $\mathrm{Rx})$ when neoplastic tissue was present at the margins of an EMR specimen and additional resections at the periphery of the tumor could not be oriented clearly with regard to the involved margin.

All procedures were carried out by experienced gastrointestinal endoscopists (T.R., H.N., B.S.) with special experience in polypectomy and EMR. The patients were under sedation; small amounts of midazolam (2.5 mg) plus propofol $(250-1250 \mathrm{mg})$ were used at center $\mathrm{A}$, and $7.5 \mathrm{mg}$ midazolam plus propofol
(140-1900 mg) at center B. Procedure details (e.g. time taken, accessories, approach) were recorded. Follow-up information, for example from repeat endoscopy and surgery, was obtained if available. The aim of the present pilot series, however, was not medium- or long-term clinical efficacy, but immediate technical and clinical success as well as complications. Therefore, statistical evaluation was not done.

\section{Results}

The results from 37 patients with 38 lesions ( 23 with 24 mucosal lesions and 14 with 14 submucosal lesions) are reported.

\section{Technical Performance}

The details of the patients, techniques used and the results are shown in Table 1; one patient (H.L.) had two mucosal adenocarcinomas in his long Barrett's esophagus, and these two cancers are recorded as two separate lesions in Table $\mathbf{1}$ and in the following calculations. All the SMTs except one and 16 of the mucosal lesions were treated at center $\mathrm{A}$. The mean size of the mucosal lesions was $17.9 \mathrm{~mm}$ (range $2-50 \mathrm{~mm}$ ). $25 \%$ were less than $10 \mathrm{~mm}, 33 \%$ were between $10 \mathrm{~mm}$ and $19 \mathrm{~mm}$, and $42 \%$ were $20 \mathrm{~mm}$ and larger. The mean size of the SMTs was $23.1 \mathrm{~mm}$ (range $15-40 \mathrm{~mm}$ ). In one patient (E.B.) with Barrett's adenocarcinoma, the insulated-tip knife could not be used for cutting due to significant bleeding after the first incision (portal hypertension). The procedure for this patient was recorded in the intention-to-treat-analysis as a failure. She was subsequently treated with repeated banding (without ensuing polypectomy) and beamer therapy, as her lesion was considered inoperable.

Resection of mucosal lesions: As outlined in the Patients and Methods section, the procedure of initial circumcision was changed at center A during the series. It was felt that the preparation of the specimen from the underlying muscularis propria was easier after initial circumferential cap mucosectomies, since the muscularis layer could be reliably exposed and the cutting could be better started from there. A side-viewing scope was intermittently used in one patient with gastric antral cancer, but was not felt to be much superior. A double-channel endoscope was used in two patients (one early gastric cancer, one gastric SMT). Without elevation and movement of channels, the double-channel endoscope was not found to be of particular help for preparation and dissection, but was useful for repeated saline injection since the needle could be kept in the second channel, avoiding the need for exchange it with the insulatedtip knife that occurred with the single-channel instrument. Examples are shown in Figures 5-9. Videos demonstrating the dissection in the case shown in Figure $\mathbf{6}$ (videos v1, see http://www.thieme.de/aktionen/endovideo/video1_endo9_04.mpg and $\mathbf{v 2}$, see http://www.thieme.de/aktionen/endovideo/video2_endo9_04.mpg).

Video 1 Use of the insulated-tip knife in the case shown in Figure $\mathbf{6}$, for the dissection of the mucosal lesion from the underlying muscularis, in retroversion.

Video 2 The same same case as in video [V1] during the same session: here the dissection is beeing done in a prograde fashion. 
Table 1 Patient and lesion details of all 35 patients; data are from 23 patients with 24 mucosal lesions and 12 patients with 12 submucosal tumors

\begin{tabular}{|c|c|c|c|c|c|c|c|c|c|c|}
\hline Patient & Sex & $\begin{array}{l}\text { Age, } \\
\text { years }\end{array}$ & $\begin{array}{l}\text { Lesion } \\
\text { Type on } \\
\text { biopsy }\end{array}$ & $\begin{array}{l}\text { Location, cm } \\
\text { from incisors/ } \\
\text { esoghagus }\end{array}$ & Size, $\mathbf{m m}$ & $\begin{array}{l}\text { EMR procedure } \\
\text { Technique }\end{array}$ & $\begin{array}{l}\text { Results of end } \\
\text { One or two } \\
\text { major pieces, } \\
\text { size in } \mathrm{mm}\end{array}$ & $\begin{array}{l}\text { oresection* } \\
\text { Piecemeal, } \\
\text { number of } \\
\text { pieces }\end{array}$ & Histology & $\begin{array}{l}\text { Findings at } \\
\text { surgery }\end{array}$ \\
\hline \multicolumn{11}{|c|}{ Mucosal lesions } \\
\hline \multicolumn{11}{|c|}{ Esophagus - squamous epithelium } \\
\hline W. Ha. & M & 53 & $\mathrm{Ca}$ & $25-28$ & $\begin{array}{l}10 \text { (Ca) } \\
18(\mathrm{HG}-\mathrm{IN})\end{array}$ & $\begin{array}{l}\text { Cap, insulated- } \\
\text { tip knife, snare }\end{array}$ & & & $\begin{array}{l}\text { T1sm, G3 } \\
\text { R1 depth/lat. }\end{array}$ & $\begin{array}{l}\text { T2 } \\
\text { N0 (0/15) }\end{array}$ \\
\hline H. M. & $\mathrm{F}$ & 66 & $\mathrm{Ca}$ & $26-28$ & 30 & $\begin{array}{l}\text { Insulated-tip } \\
\text { knife, cap, snare }\end{array}$ & & & $\begin{array}{l}\text { T1sm1, G1 } \\
\text { R1 depth/lat. }\end{array}$ & $\begin{array}{l}\text { Tis } \\
\text { N0 }(0 / 31)\end{array}$ \\
\hline \multicolumn{11}{|c|}{ Barrett esophagus } \\
\hline E. B. & $\mathrm{F}$ & 78 & HG-IN & $\begin{array}{l}25 \text { (long } \\
\text { Barrett } 5 \mathrm{~cm} \text { ) }\end{array}$ & ca. $15^{\text {b }}$ & $\begin{array}{l}\text { Attempted } \\
\text { insulated-tip, } \\
\text { bleeding } \\
\text { Banding, } \\
\text { beamer }^{\text {b }}\end{array}$ & Only biopsies, & no specimen & & - \\
\hline W. W. & M & 54 & HG-IN & $\begin{array}{l}34 \text { (long } \\
\text { Barrett } 6 \mathrm{~cm} \text { ) }\end{array}$ & 2 & $\begin{array}{l}\text { Semicircumfer- } \\
\text { ential, Cap, insu- } \\
\text { lated-tip, snare } \\
\text { Regrowthc }\end{array}$ & & 5 & LG-IN, RO & - \\
\hline E. K. & M & 74 & Ca G1 & $\begin{array}{l}30 \text { (long } \\
\text { Barrett } 9 \mathrm{~cm} \text { ) }\end{array}$ & $\begin{array}{l}2(\mathrm{Ca})+ \\
4(\mathrm{HG}-\mathrm{IN})\end{array}$ & $\begin{array}{l}\text { Capt, insulated- } \\
\text { tip knife, snare }\end{array}$ & $63 \times 16$ & & $\begin{array}{l}\text { T1m, G2, R0 } \\
\text { HG-IN, R0 }\end{array}$ & - \\
\hline $\begin{array}{l}\text { H. L. } \\
\text { (two } \\
\text { lesions) }\end{array}$ & M & 67 & HG-IN & $\begin{array}{l}32 \mathrm{~cm} \\
26 \mathrm{~cm} \\
\text { (long Barrett } \\
14 \mathrm{~cm} \text { ) }\end{array}$ & $\begin{array}{r}7 \\
12\end{array}$ & $\begin{array}{l}\text { Capt, insulated- } \\
\text { tip knife, snare }\end{array}$ & $\begin{array}{l}40 \times 10 \\
13 \times 10\end{array}$ & & $\begin{array}{l}\text { T1m, G1, R1 } \\
\text { T1m, G1, R1 }\end{array}$ & $\begin{array}{l}- \\
-\end{array}$ \\
\hline E. A. & M & 79 & Ca G2 & $\begin{array}{l}25 \mathrm{~cm} \text { (long } \\
\text { Barrett } 10 \mathrm{~cm} \text { ) }\end{array}$ & $\begin{array}{l}2(\mathrm{Ca}) \text { in } \\
30(\mathrm{HG}-\mathrm{IN})\end{array}$ & $\begin{array}{l}\text { Capt, insulated- } \\
\text { tip knife, snare }\end{array}$ & $40 \times 15$ & & $\begin{array}{l}\text { T1m, G2, R1 lat. } \\
\text { (HG-IN) }\end{array}$ & - \\
\hline W. B. & M & 62 & Ca G2 & $\begin{array}{l}36-38 \mathrm{~cm} \\
\text { (Barrett } 3 \mathrm{~cm} \text { ) }\end{array}$ & 20 & $\begin{array}{l}\text { Insulated-tip } \\
\text { knifeł }\end{array}$ & $26 \times 20$ & & $\begin{array}{l}\text { T1m, G2, R1 } \\
\text { R1 lateral }\end{array}$ & - \\
\hline N.W. & M & 55 & Ca G2 & $\begin{array}{l}42-44 \mathrm{~cm} \\
\text { (Barrett } 2 \mathrm{~cm} \text { ) }\end{array}$ & 20 & $\begin{array}{l}\text { Insulated-tip } \\
\text { knife, snare }\end{array}$ & $22 \times 15$ & & $\begin{array}{l}\text { T1sm3, G2, } \\
\text { R1 depth/lat. }\end{array}$ & T0, N0 \\
\hline M. M. & M & 64 & $\mathrm{Ca} G 1^{\mathrm{e}}$ & $37 \mathrm{~cm}^{\mathrm{e}}$ & 3 & $\begin{array}{l}\text { Cap, insulated- } \\
\text { tip knife }\end{array}$ & $10 \times 12$ & & T1m, G1, R0 & $\begin{array}{l}+ \text { After- } \\
\text { loading }\end{array}$ \\
\hline \multicolumn{11}{|c|}{ Gastric lesions (cancer, HG-IN and LG-IN) } \\
\hline K. H. & M & 77 & Ca G2 & Cardia, LC & 20 & $\begin{array}{l}\text { Cap, insulated- } \\
\text { tip knife, snare }\end{array}$ & $50 \times 40$ & & $\begin{array}{l}\text { T1m, G2, } \\
\text { R1 lateral }\end{array}$ & $\begin{array}{l}\text { T0 } \\
\text { N0 (0/17) }\end{array}$ \\
\hline K. E. & M & 81 & $\mathrm{Ca} \mathrm{G} 3^{f}$ & Cardia, LC & 31 & $\begin{array}{l}\text { Capt, insulated- } \\
\text { tip knife, snare }\end{array}$ & $\begin{array}{l}15 \times 13 \\
18 \times 16\end{array}$ & 4 & $\begin{array}{l}\text { T1m, G3 } \\
\text { lat/depth }\end{array}$ & $\begin{array}{l}\text { T1m } \\
\text { N } 0(0 / 7)\end{array}$ \\
\hline C. M. & $\mathrm{F}$ & 79 & $\mathrm{Ca} \mathrm{G} 2^{\mathrm{g}}$ & Cardia, LC & 15 & $\begin{array}{l}\text { Cap; insulated- } \\
\text { tip knife and } \\
\text { snare only com- } \\
\text { plementary }\end{array}$ & & & T1m, G2, Rx & $\begin{array}{l}\text { T0 } \\
\text { N0 (0/16) }\end{array}$ \\
\hline H. S. & $\mathrm{F}$ & 66 & $\begin{array}{l}\text { Polyp, } \\
\text { HG-IN }\end{array}$ & Cardia, LC & 15 & $\begin{array}{l}\text { Capt, insulated- } \\
\text { tip knife, snare }\end{array}$ & $25 \times 15$ & & HG-IN, RO & - \\
\hline J. G. & M & 77 & Ca G2 & Body, PW & 11 & $\begin{array}{l}\text { Cap, insulated- } \\
\text { tip knife, snare }\end{array}$ & $19 \times 19$ & & T1m, R0 & - \\
\hline W. S. & M & 74 & Ca G2 & Body, GC & 10 & $\begin{array}{l}\text { Cap, insulated- } \\
\text { tip knife, snare }\end{array}$ & $20 \times 18$ & & T1sm, G3, R1 & $\begin{array}{l}\text { T0/HGD } \\
\text { NO }(0 / 17)\end{array}$ \\
\hline M. P. & M & 86 & Ca G1 & $\begin{array}{l}\text { Antrum, } \\
\text { AW, LC }\end{array}$ & 4 & $\begin{array}{l}\text { Cap, insulated- } \\
\text { tip, SV endo- } \\
\text { scope snare }\end{array}$ & $35 \times 25$ & & T1m, R0 & - \\
\hline E. S. & M & 63 & $\begin{array}{l}\text { Ca G3 } \\
\text { Signet-cell ca }\end{array}$ & Antrum, LC & 30 & $\begin{array}{l}\text { Insulated-tip } \\
\text { knife }\end{array}$ & $\begin{array}{l}38 \times 27 \\
16 \times 8\end{array}$ & & $\begin{array}{l}\text { T1m,.R1 } \\
\text { lateral }\end{array}$ & $\begin{array}{l}\text { T0 } \\
\text { N0 (0/25) }\end{array}$ \\
\hline B. E. & $\mathrm{M}$ & 71 & $\begin{array}{l}\text { LG-IN } \\
\text { (adenoma) }\end{array}$ & Antrum, LC & 20 & $\begin{array}{l}\text { Insulated-tip } \\
\text { knife }\end{array}$ & $28 \times 17$ & & $\begin{array}{l}\text { T1m, G1, } \\
\text { R1 lateral }\end{array}$ & - \\
\hline W. H. & $\mathrm{M}$ & 82 & $\begin{array}{l}\text { LG-IN } \\
\text { (adenoma) }\end{array}$ & Antrum, LC & 40 & $\begin{array}{l}\text { Insulated-tip kni- } \\
\mathrm{fe}^{\mathrm{h}} \text {, snare }\end{array}$ & & 5 & $\begin{array}{l}\mathrm{T} 1 \mathrm{~m}, \mathrm{G} 1 \\
\mathrm{Rx}^{\mathrm{d}}\end{array}$ & - \\
\hline M. H. & $\mathrm{F}$ & 75 & $\begin{array}{l}\text { LG-IN } \\
\text { (adenoma) }\end{array}$ & Antrum, LC & 50 & $\begin{array}{l}\text { Cap, insulated- } \\
\text { tip knife, snare } \\
\text { Cap EMR }\end{array}$ & & 8 & LG-IN, Rx & - \\
\hline H. K. & $\mathrm{F}$ & 69 & $\begin{array}{l}\text { LG-IN } \\
\text { (adenoma) }\end{array}$ & Antrum, AW & 15 & $\begin{array}{l}\text { Insulated-tip } \\
\text { knife, snare }\end{array}$ & $17 \times 15$ & & LG-IN, R0 & - \\
\hline
\end{tabular}


Table 1 Continuation

\begin{tabular}{|c|c|c|c|c|c|c|c|c|c|c|}
\hline Patient & Sex & $\begin{array}{l}\text { Age, } \\
\text { years }\end{array}$ & $\begin{array}{l}\text { Lesion } \\
\text { Type on } \\
\text { biopsy }\end{array}$ & $\begin{array}{l}\text { Location, cm } \\
\text { from incisors/ } \\
\text { esoghagus }\end{array}$ & Size, mm & $\begin{array}{l}\text { EMR procedure } \\
\text { Technique }\end{array}$ & $\begin{array}{l}\text { Results of end } \\
\text { One major } \\
\text { piece, } \\
\text { size in } \mathrm{mm}\end{array}$ & $\begin{array}{l}\text { Two pieces, } \\
\text { sizes of each } \\
\text { in } \mathrm{mm}\end{array}$ & Histology & $\begin{array}{l}\text { Findings at } \\
\text { surgery }\end{array}$ \\
\hline M. D. & $\mathrm{F}$ & 73 & $\begin{array}{l}\text { LG-IN } \\
\text { (adenoma) }\end{array}$ & Body, AW & 8 & $\begin{array}{l}\text { Insulated-tip } \\
\text { knife }\end{array}$ & $20 \times 15$ & & $\begin{array}{l}\text { LG-IN, R1 } \\
\text { laterald }^{d}\end{array}$ & - \\
\hline \multicolumn{11}{|c|}{ Submucosal lesions } \\
\hline \multicolumn{11}{|c|}{ Esophagus } \\
\hline C. N. & $M$ & 36 & SMT & $38 \mathrm{~cm}$ & 15 & $\begin{array}{l}\text { Cap, insulated- } \\
\text { tip knife, snare }\end{array}$ & $16 \times 10 \times 7$ & & $\begin{array}{l}\text { Leiomyoma, } \\
\text { CR }\end{array}$ & - \\
\hline H. G. & $\mathrm{M}$ & 55 & SMT & $26 \mathrm{~cm}$ & 13 & $\begin{array}{l}\text { Cap, insulated- } \\
\text { tip knife, snare }\end{array}$ & $16 \times 8 \times 10$ & & $\begin{array}{l}\text { Granular cell } \\
\text { tumor, CR }\end{array}$ & - \\
\hline \multicolumn{11}{|c|}{ Stomach } \\
\hline L. H. & $\mathrm{M}$ & 43 & SMT & Cardia, GC & 20 & $\begin{array}{l}\text { Cap, insulated- } \\
\text { tip knife, snare }\end{array}$ & $20 \times 15 \times 15$ & & $\begin{array}{l}\text { Leiomyoma, } \\
\text { CRx }\end{array}$ & - \\
\hline G. E. & $\mathrm{F}$ & 54 & SMT & Body, PW & 15 & $\begin{array}{l}\text { Cap, insulated- } \\
\text { tip knife, snare }\end{array}$ & & $\begin{array}{l}15 \times 7 \\
7 \times 4\end{array}$ & $\begin{array}{l}\text { Neurofibroma, } \\
\text { CR }\end{array}$ & - \\
\hline A. F. & $M$ & 67 & SMT & Body, LC & 30 & $\begin{array}{l}\text { Cap, insulated- } \\
\text { tip knife, snare }\end{array}$ & & $\begin{array}{l}18 \times 12 \\
14 \times 10\end{array}$ & $\begin{array}{l}\text { Aberrant } \\
\text { pancreas }\end{array}$ & \\
\hline G. H. & $\mathrm{M}$ & 70 & $\mathrm{SMT}^{\prime}$ & Body, PW & 35 & Cap, suction' & & $\begin{array}{l}25 \times 15 \times 10 \\
10 \times 10 \times 8\end{array}$ & Lipoma & \\
\hline I. A. & $\mathrm{F}$ & 72 & SMT & Body, LC & 20 & $\begin{array}{l}\text { Cap, insulated- } \\
\text { tip knife, snare }\end{array}$ & $20 \times 20 \times 13$ & & $\begin{array}{l}\text { GIST, 2/50 HPF } \\
\text { CR }\end{array}$ & $\mathrm{m}$ \\
\hline R. B. & $\mathrm{M}$ & 61 & SMT & Body, PW & 15 & $\begin{array}{l}\text { Cap, insulated- } \\
\text { tip knife, snare }\end{array}$ & & $\begin{array}{l}6 \times 4 \\
9 \times 6\end{array}$ & $\begin{array}{l}\text { GIST, } 1 / 50 \text { HPF } \\
\text { CRx }\end{array}$ & - \\
\hline H. M. & $\mathrm{F}$ & 55 & SMT & Body, LC & 20 & $\begin{array}{l}\text { Cap, insulated- } \\
\text { tip knife, snare }\end{array}$ & $16 \times 15 \times 15$ & & $\begin{array}{l}\text { GIST, 6/50 HPF } \\
\text { CR }\end{array}$ & - \\
\hline H. K. & $\mathrm{M}$ & 71 & SMT & Antrum, AW & 30 & $\begin{array}{l}\text { Cap, insulated- } \\
\text { tip knife, snare }\end{array}$ & & $\begin{array}{l}24 \times 18 \\
18 \times 15\end{array}$ & $\begin{array}{l}\text { GIST, 0/50 HPF } \\
\text { CR }\end{array}$ & - \\
\hline K. W. & $\mathrm{M}$ & 65 & SMT & Antrum, PW & 20 & $\begin{array}{l}\text { Cap, insulated- } \\
\text { tip knife, snare }\end{array}$ & $17 \times 12$ & & $\begin{array}{l}\text { GIST, } 1 / 50 \text { HPF } \\
\text { CRx }\end{array}$ & - \\
\hline B. T. & M & 66 & Lipoma' & Antrum, PW & 40 & Cap, suction' & $40 \times 30 \times 20$ & & Lipoma & - \\
\hline L. O. & $\mathrm{F}$ & 75 & $\begin{array}{l}\text { SMT or } \\
\text { erosion }\end{array}$ & Antrum, GC & 20 & $\begin{array}{l}\text { Insulated-tip } \\
\text { knife }\end{array}$ & $25 \times 17 \times 4$ & & GIFT, CR & - \\
\hline \multicolumn{11}{|c|}{ Duodenum } \\
\hline F. K. & $\mathrm{M}$ & 76 & $\mathrm{SMT}^{\prime}$ & $\begin{array}{l}\text { Duodenal } \\
\text { bulb }\end{array}$ & 30 & $\begin{array}{l}\text { Cap, insulated- } \\
\text { tip knife, suction }\end{array}$ & & $\begin{array}{l}10 \times 10 \\
8 \times 8\end{array}$ & Lipoma, CR & \\
\hline
\end{tabular}

\section{Abbreviations and explanations:}

Ca, cancer; HG/LG-IN, high-grade/low-grade intraepithelial neoplasia (dysplasia); G1/2/3, grading highly/moderately/poorly differentiated cancer type; A/ PW, anterior/posterior wall; G/LC, greater/lesser curvature; cap, cap mucosectomy; snare, snare resection at final stage ( ${ }^{*}$ snare resection in intermittent stage, see text); SV endoscope, side-viewing endoscope; DC endoscope, double-channel endoscope; EMR, endoscopic mucosal resection; SMT, submucosal tumor of unclear etiology; R0, complete resection; R1, incomplete resection; Rx, completeness of resection indeterminable; $C R$, complete resection; $\mathrm{CRx}$, complete resection uncertain; GIST, gastrointestinal stromal cell tumor (CD-177-positive); HPF, number of mitoses per 50 high-power field (indicates benign or malignant nature of the tumor); GIFT, gastrointestinal fibrous stromal tumor.

* One major piece resected, some small fragments at the margin removed by snare or biopsy forceps; the size inmm here denotes the size of the piece(s) resected. If piecemeal resection was performed, the number of pieces is given, and the size may be shown inmm.

$\dagger$ Modification of the initial technique (see text): three to four conventional cap mucosectomies at/outside of the marked margins of the lesion; cutting with insulated-tip knife between these margins; preparation of the specimen (en bloc attempted). Cap mucosectomies usually spanned an area of approximately $10 \times 10 \mathrm{~mm}$.

$\ddagger$ Use of a small cap as for magnification endoscopy.

a Only isolation was done with the insulated-tip knife. Dissection with insulated-tip knife was insufficient due to central depression of the lesion. EMR with the cap technique also failed. Resection was continued by use of a simple snare.

b Since the patient could not be operated upon and had portal hypertension with small varices, insulated-tip knife preparation was halted due to significant bleeding. Several sessions of multibanding (without ensuing resection) and argon beamer therapy were carried out with complete re-epithelialization of the distal esophagus with squamous epithelium. Control biopsies showed no residual tumor.

c Despite complete mucosal resection in two large and several small pieces, the patient probably did not subsequently take proton pump inhibitors. Regrowth was observed at the first control, and, due to refusal of surgery, endotherapy was continued with EMR and argon beamer therapy, with complete Barrett's removal. Follow-up biopsies of more than 3 months are pending.

${ }^{d}$ Despite R1 (lateral) or Rx resection, no evidence of residual tissue of the original lesion was found during follow-up with endoscopy and biopsy specimen at 20 weeks (patients B.E., M.D.) and 39 weeks (patient W.H), or at further EMR for ablation of Barrett's mucosa with a subsequent follow-up of 29 weeks (patient W.B.).

e The patient had been treated for Barrett's esophagus with multiple HG-IN by piecemeal cap EMR plus beamer, but suffered from local recurrence 1 year later. Despite complete removal of this local recurrence by insulated-tip knife EMR, a decision was made to additionally apply intraluminal brachytherapy (afterloading).

${ }^{f}$ Repeated biopsies pre-EMR showed only HG-IN.

$g$ Endoscopy and EUS suggested possible T1sm, so, due to restricted operabil- 
ity, EMR was attempted, but felt to be macroscopically incomplete (R2). Biopsies on repeat endoscopy showed remaining tumor cells in one biopsy spot.

${ }^{\mathrm{h}}$ Complete dissection of the lesion failed due to a central ulceration (Ila $+\mathrm{c}$ ), piecemeal resection with a snare followed dissection of the lateral borders with an insulated-tip knife.

i Completeness of resection could not be assessed, since the large area $(5 \times$ $3 \mathrm{~cm}$ ) could not be resected in one piece, but was removed using a combination of multiple cap mucosectomies and preparations with the insulated-tip knife. For sole removal using the insulated-tip knife the angle toward the lesions was not favorable. On repeat endoscopy 4 months later, circumferential biopsies around the area showed adenoma (LG-IN) in only one biopsy at the distal margin at the 6 o'clock position (GC). k After resection, small amounts of air could be seen in the mediastinum and in the lateral neck; the patient also felt pain. Conservative management was successful (see text).

'Endosopic removal of lipomas consists of cap mucosectomy of overlying mucosa and suction of the lipoma using the cap; resection by insulated-tip knife or snare was usually not necessary. In patients G. H. and F. K. lipoma was not suspected on the basis of EUS; in patient B. T. the large lipoma (diagnosed as such on EUS) was adjacent to the pylorus and caused gastric outlet delay with reflux esophagitis, and this was confirmed on gastric scintigraphy.

m Control 6 months after resection showed a $10 \times 4$-mm echo-free lesion at the muscularis propria, which was punctured by EUS. The histological and cytological features were compatible with the diagnosis of hematoma. a
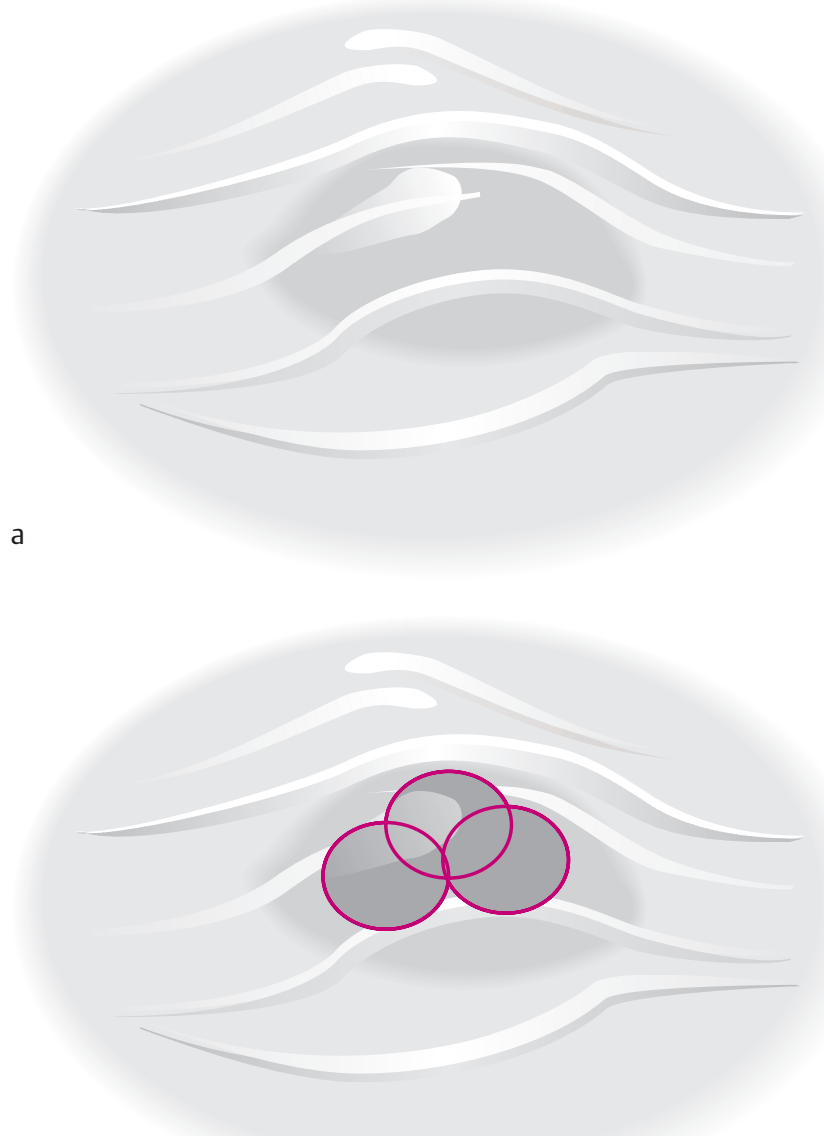

b

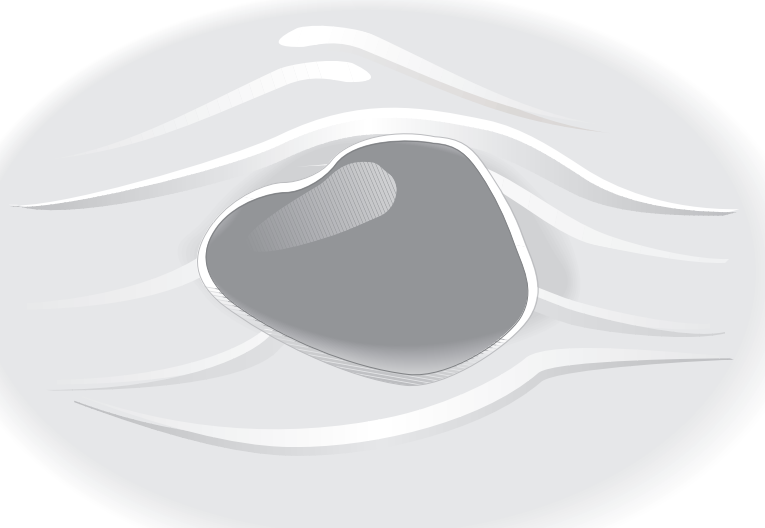

Figure 4 Schematic representation of the steps in the removal of submucosal tumors using superficial cap mucosectomy, cap suction, and insulated-tip knife dissection, described in detail in the text. a The submucosal tumor is identified. $\mathbf{b}$ The overlying mucosa is resected using

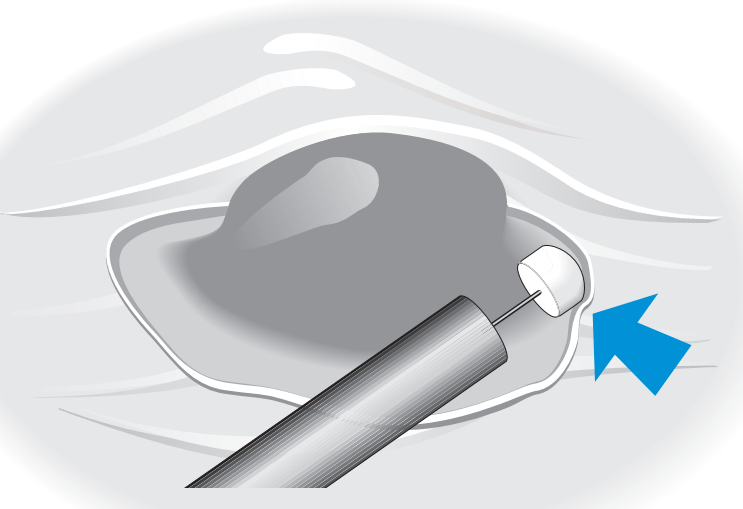

d
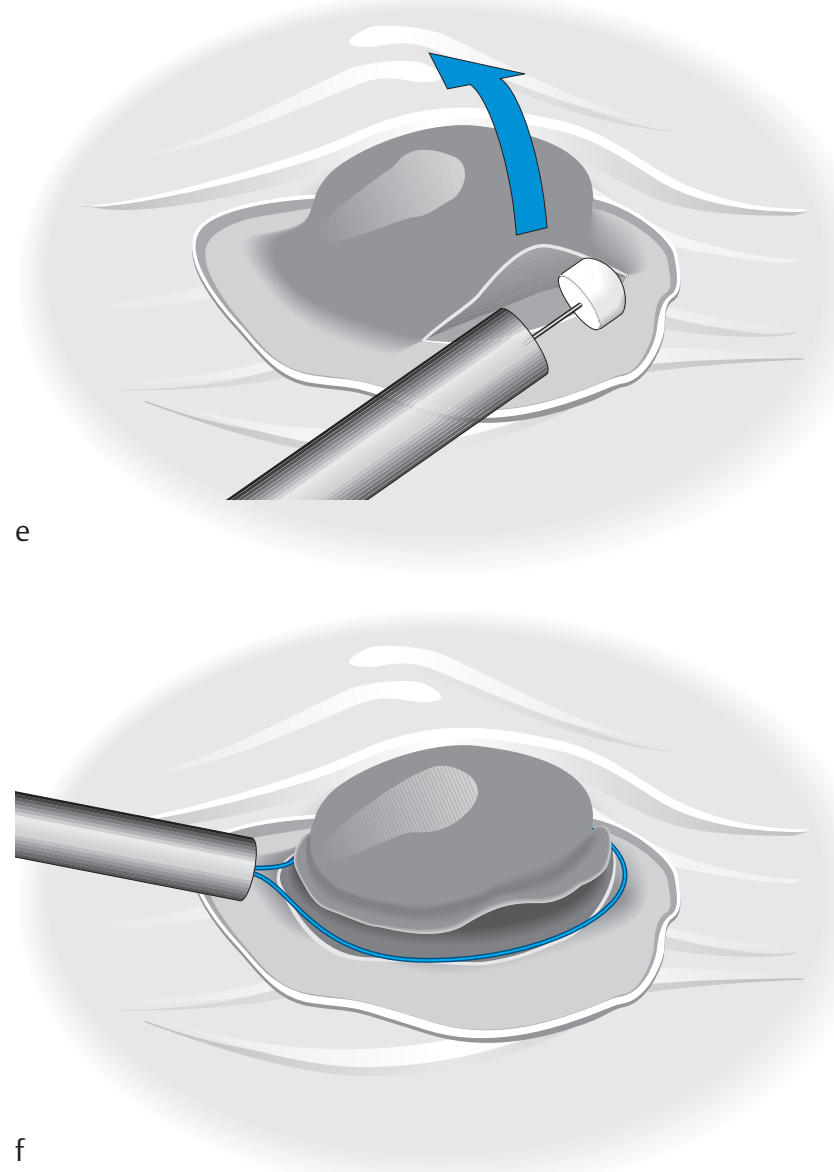

cap mucosectomy. c The uncovered tumor. d, e The tumor is further dissected using the insulated-tip knife. $\mathbf{f}$ Finally it is resected with a conventional polypectomy snare. 

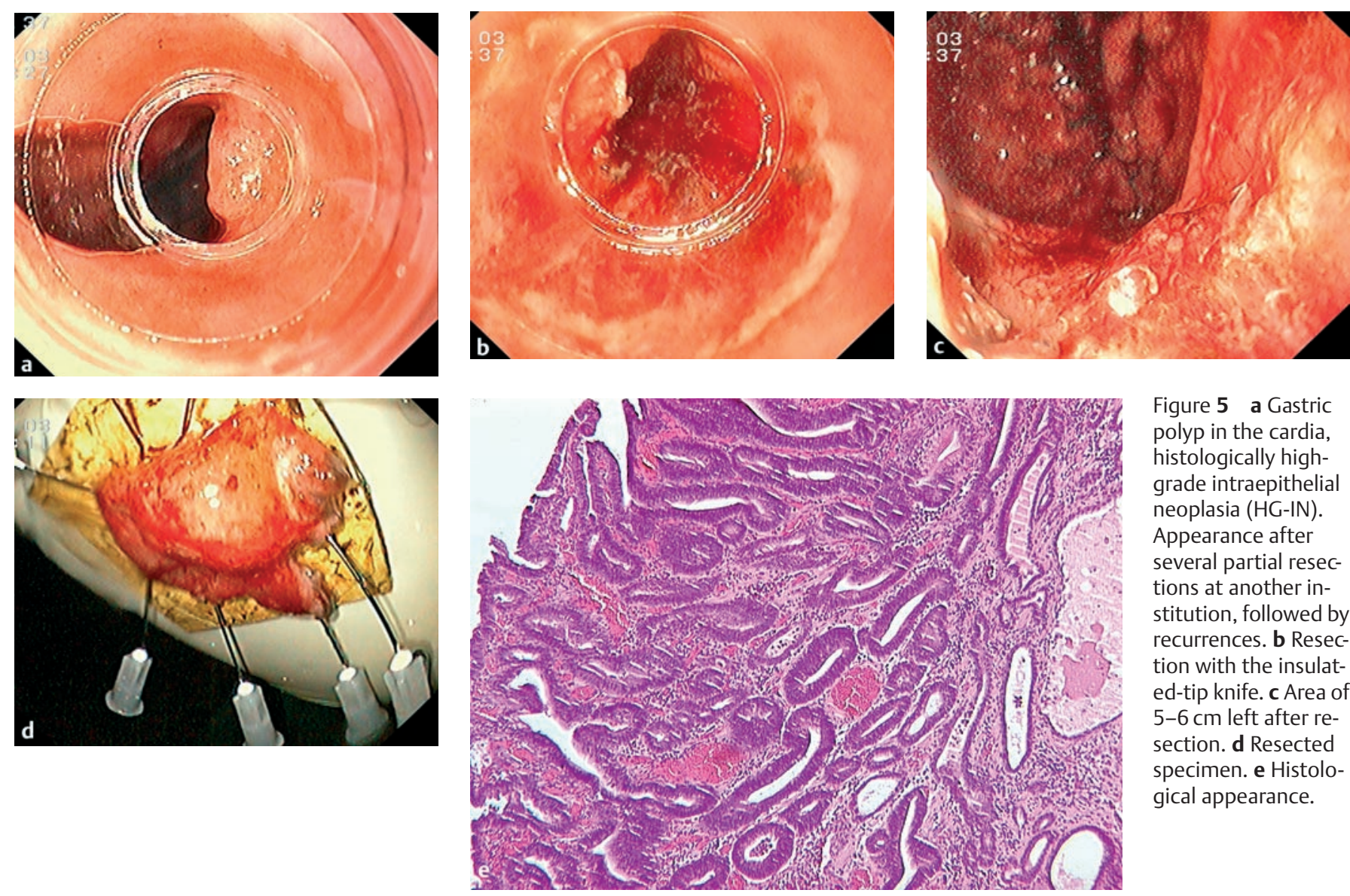

Figure 5 a Gastric polyp in the cardia, histologically highgrade intraepithelial neoplasia (HG-IN). Appearance after several partial resections at another institution, followed by recurrences. b Resection with the insulated-tip knife. c Area of 5-6 cm left after resection. d Resected specimen. e Histological appearance.
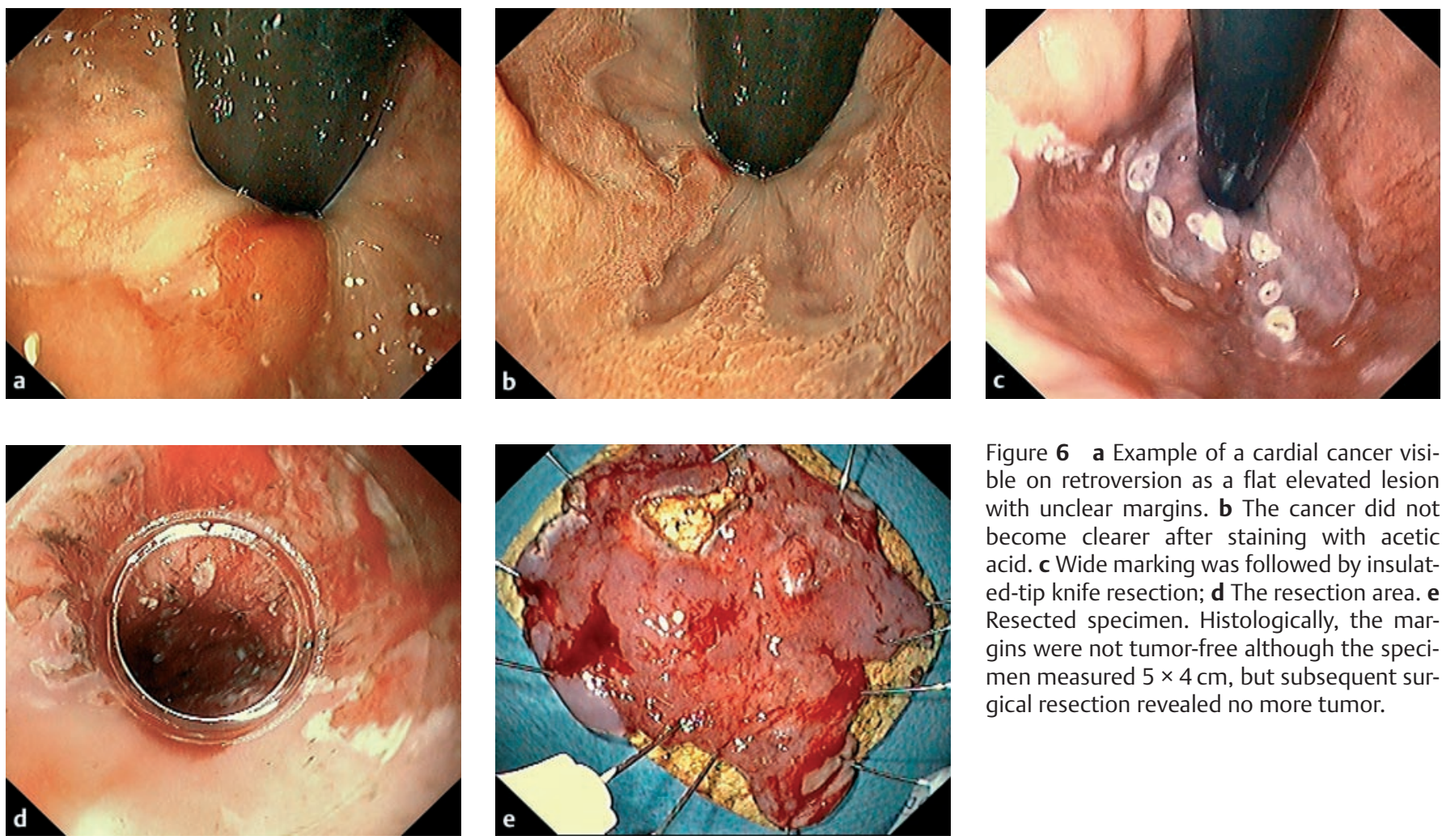

Figure 6 a Example of a cardial cancer visible on retroversion as a flat elevated lesion with unclear margins. b The cancer did not become clearer after staining with acetic acid. c Wide marking was followed by insulated-tip knife resection; $\mathbf{d}$ The resection area. e Resected specimen. Histologically, the margins were not tumor-free although the specimen measured $5 \times 4 \mathrm{~cm}$, but subsequent surgical resection revealed no more tumor. 

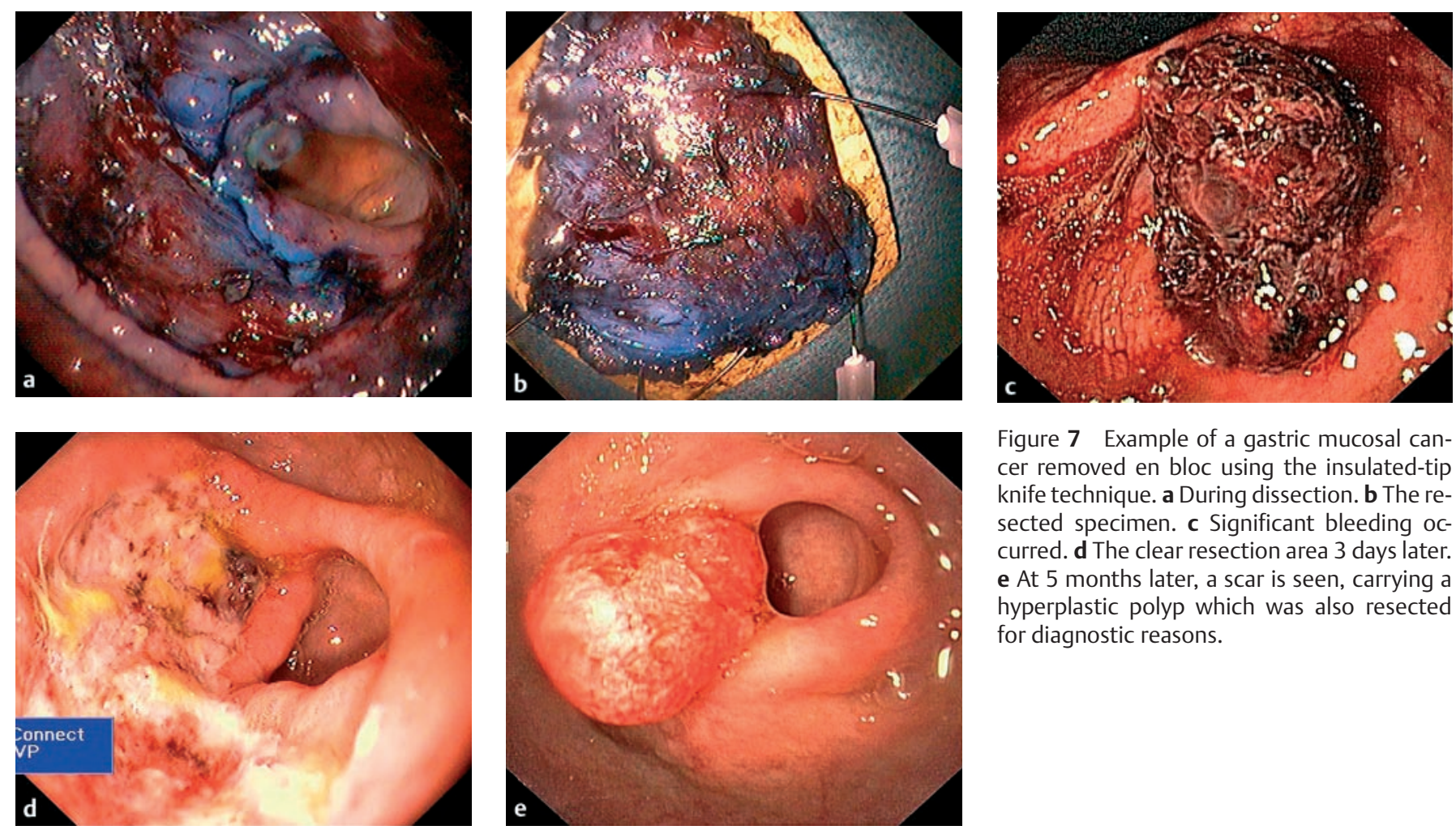

Figure 7 Example of a gastric mucosal cancer removed en bloc using the insulated-tip knife technique. a During dissection. $\mathbf{b}$ The resected specimen. c Significant bleeding occurred. $\mathbf{d}$ The clear resection area 3 days later. e At 5 months later, a scar is seen, carrying a hyperplastic polyp which was also resected for diagnostic reasons.

Procedure time ranged between 45 minutes and 2 hours. The initial circumcision was felt to be the easiest step and was usually accomplished within 10-15 minutes. The preparation of the specimen with the help of repeated saline injection was much more demanding due to the limited freedom of movement of the endoscope and the insulated-tip knife, different cutting angles depending on the location of the lesions in esophagus and stomach, and the problem of the specimen's lying or hanging in or over the field of further dissection. Sometimes, injection of larger volumes of saline kept the specimen at some distance from the underlying muscularis propria for appropriate cutting and dissection, but this rarely lasted long. Due to the mostly oblique (sometimes almost rectangular) cutting angle, dissection was almost never precisely located in the very same tissue plane, but was mostly somewhere in the lower submucosa and between the submucosa and the muscularis propria. Thus, proper separation of these two layers with smooth surfaces was rarely achieved over the entire area (Figure 9).

Resection of submucosal lesions: Dissection of the overlying mucosa was possible in all cases. Three lipomas were sucked out with the help of the cap, with the insulated-tip knife being used only intermittently for better dissection. For the other tumors, sucking them into the cap and pulling back the endoscope was only marginally helpful. They had to be actively freed from the underlying muscularis with the help of injection and cutting with the insulated-tip knife. During this process, it was often difficult to clearly differentiate the tumor base from the muscular layer in order to avoid cutting too deeply. It was also felt to be difficult to correctly discern the point at which the tumor had been 


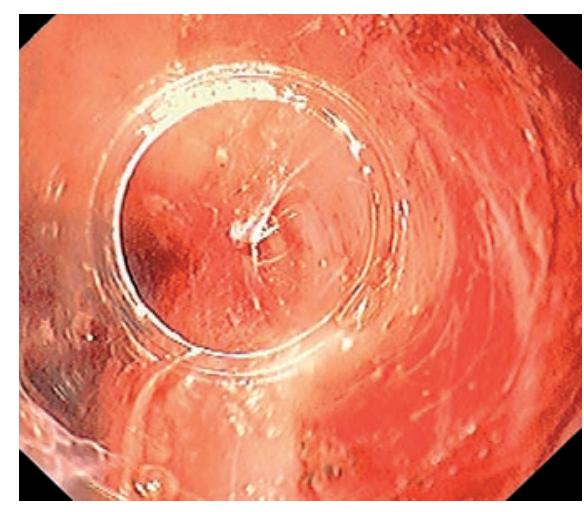

Figure 9 Clear separation from muscularis propria in a patient with Barrett's esophagus and two foci of adenocarcinoma; only a few strands of submucosal connective tissue are seen loosely covering the shiny muscularis layer. adequately separated from the underlying muscularis propria for snaring and complete resection with conventional snare polypectomy. In four cases (including one case of ectopic pancreas) snare resection proved to be premature, so that the snare cut through the tumor and the remaining piece had to be resected in a second attempt. Examples are shown in Figures 10-12.
A double-channel endoscope was used in addition in one patient (L.H., see Table 1), in whom a cardial SMT was treated in retroversion. Although completely freed, the tumor could not be snared since the well-sedated patient developed an untreatable hiccup. Only with the help of a grasping forceps, introduced through the second channel, was it possible to seize and snare the tumor.

Procedure time ranged between 1 hour and 2.5 hours. The initial cap EMR was achieved easily and took only 5-10 minutes. The preparation of the specimen with the help of repeated saline injection and insulated-tip knife dissection was much more demanding since the tumor could not be properly elevated.

\section{Summary of Immediate Clinical Effectiveness}

The details are given in Table $\mathbf{1}$, and a summary of results is given in Table 2 . The intention-to-treat-analysis shows that the study aim of complete tumor resection in one piece was achieved in only $6 / 24$ (25\%) of the mucosal lesions and 5/14 (36\%) of the submucosal lesions.

With regard to the mucosal lesions, there was one failure that could not be attributed to technical problems but to the patient's
Figure 10 Gastrointestinal stromal (GIST) tumor in the stomach. a Endoscopic view. b Endosonographic appearance. c After enucleation and snare resection, clipping was needed to stop bleeding. $\mathbf{d}$ The resected specimen.
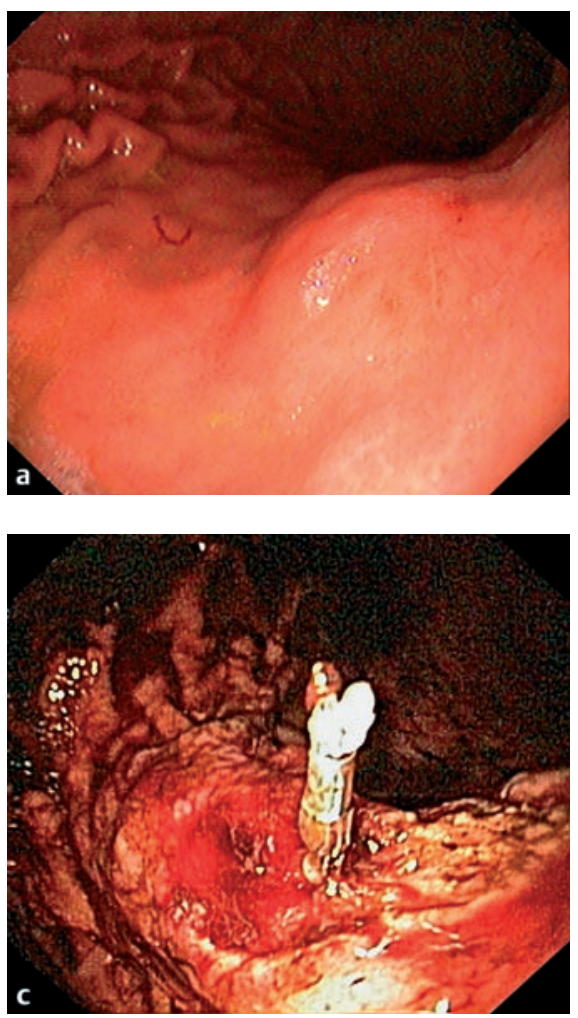
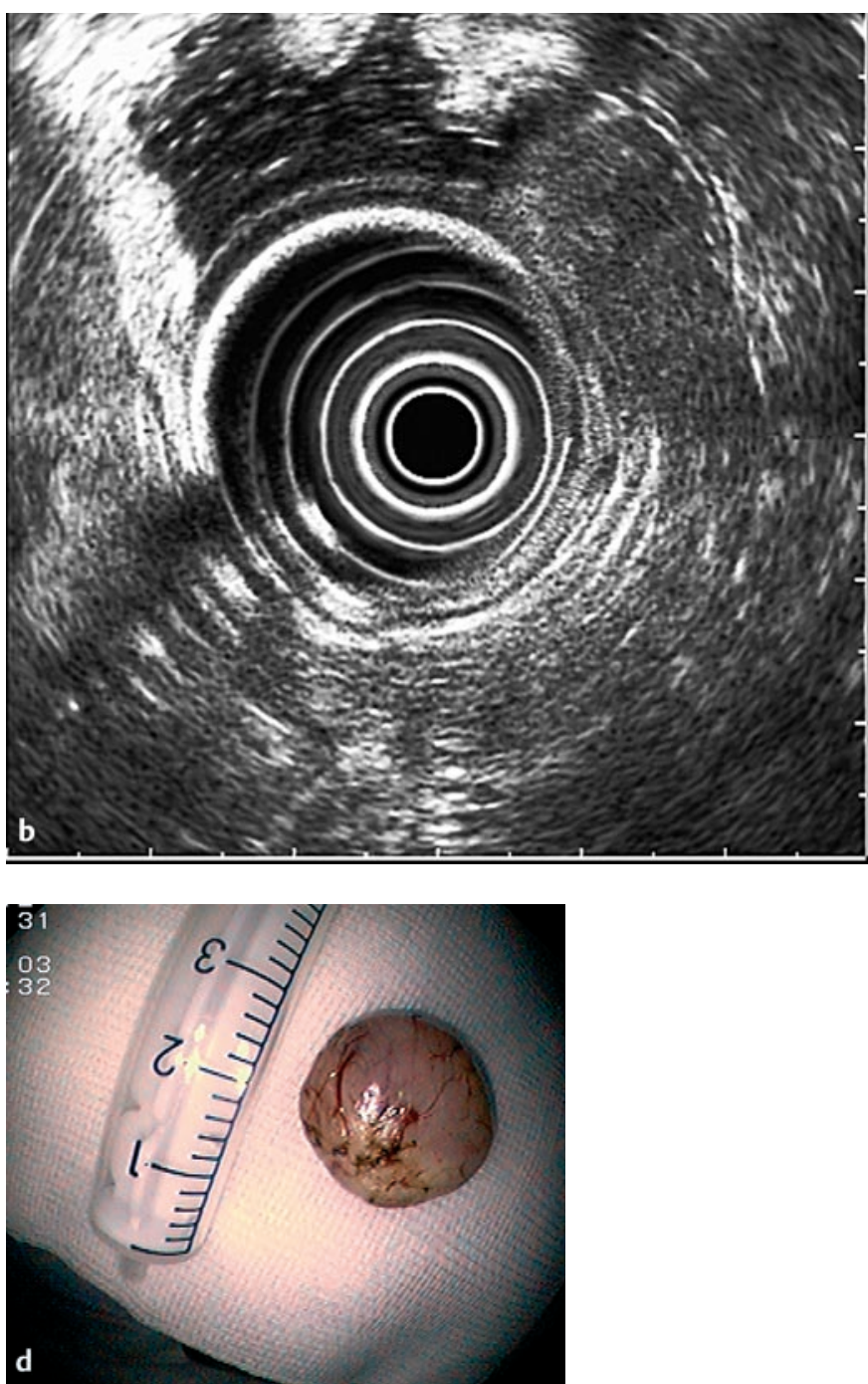

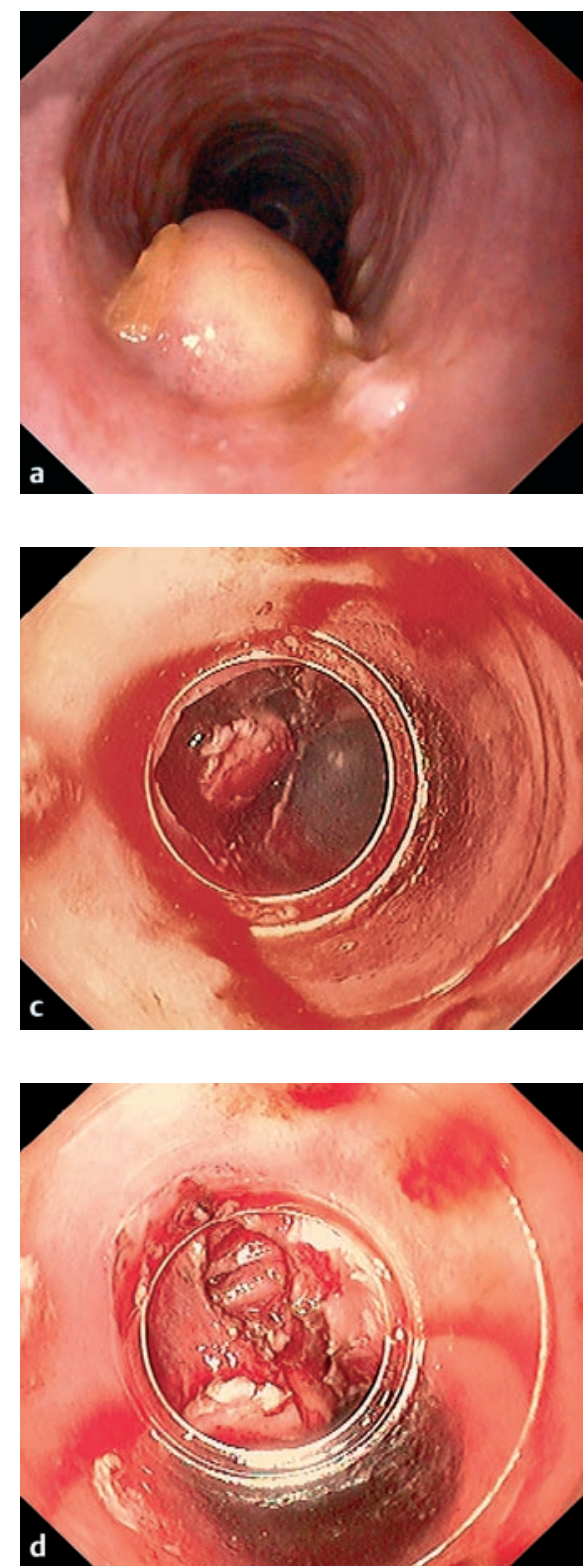

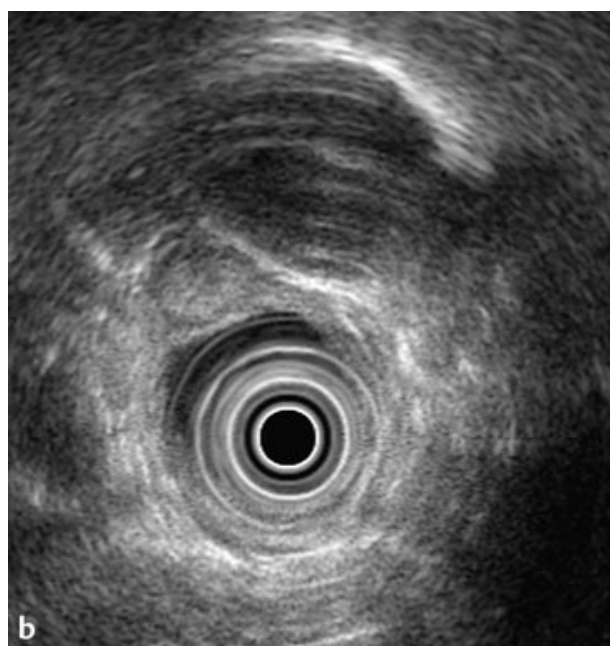

Figure 11 A granular cell tumor in the esophagus. a Endoscopic appearance. b Endosonographic view. The preprocedure diagnosis was uncertain. c After circumcision, the tumor was freed and finally resected, $\mathbf{d}$ A deep resection area with circular muscle fibers was left behind. The patient had minor perforation with some small amounts of free air, but recovered with conservative management. e The resected specimen.

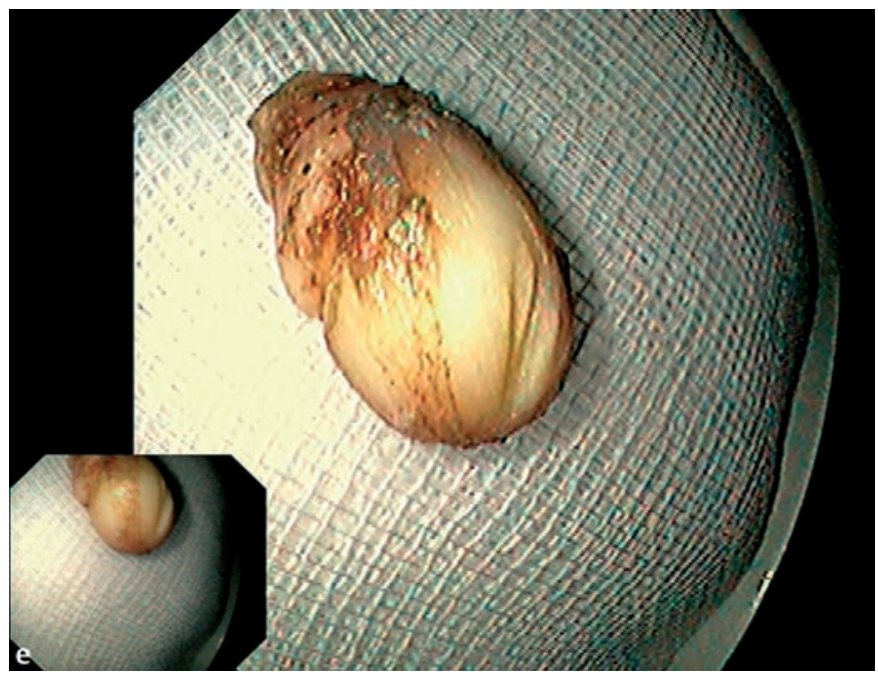

tendency to bleed, and this can be excluded from the analysis. In a further five patients, complete tumor removal was achieved at the first session using the piecemeal technique. In nine cases where the lateral margins were assessed histologically as Rx or $\mathrm{R} 1$, follow-up surgery or endoscopy with biopsy revealed no residual tumor. Using a more liberal definition, clinical success (R0 resection en bloc or piecemeal) could be assumed in 15/23 patients (65\%). It is noteworthy that $5 / 24$ cases were sm 1 tumors; subtracting these from the 23 successfully treated EMR cases would further increase the success rate $(15 / 18=83 \%)$.

In the SMT group, including a further six cases in whom the complete tumor was removed in two pieces would increase the success rate to $11 / 14$ (79\%).

\section{Complications}

Bleeding during resection that required endoscopic injection of epinephrine and placement of hemoclips was observed in six cases (four mucosal lesions, two SMT), but there were no further clinical sequelae such as re-intervention, hemoglobin drop $>1 \mathrm{~g} /$ $\mathrm{dl}$, or the need for transfusion. There was a subjective impression, that, if proper dissection could be carried out exactly between the submucosa and muscularis propria, then bleeding occurred less often, especially in cases of Barrett's esophagus.

Not counting the patient in whom the procedure could not be done due to bleeding at incision, clinically significant complications were encountered in six patients (16.6\%). One patient (M.P.) with early gastric cancer experienced hematemesis on the evening of the procedure, necessitating transfusion of two units of packed red blood cells; repeat endoscopy showed a large clot on the resection ulcer, and bleeding stopped spontaneously without intervention. Two patients, H.K. and W.B., developed delayed bleeding 24 hours and 7 days, respectively, after the procedure, during which procedure-related bleeding had been successfully controlled endoscopically; again, hemostasis was achieved by endoscopic clipping in both patients. One patient (H.L.) with two areas of Barrett's ablation had significant pain for 3-4 days after the procedure necessitating administration of central analgesics; clinical examination, repeat endoscopy, 
Figure 12 One-piece enucleation of a prepyloric lipoma which caused symptoms of gastric outlet obstruction. a Endoscopic view. b Endosonographic view. c The resected specimen. $\mathbf{d}$ The resection area.
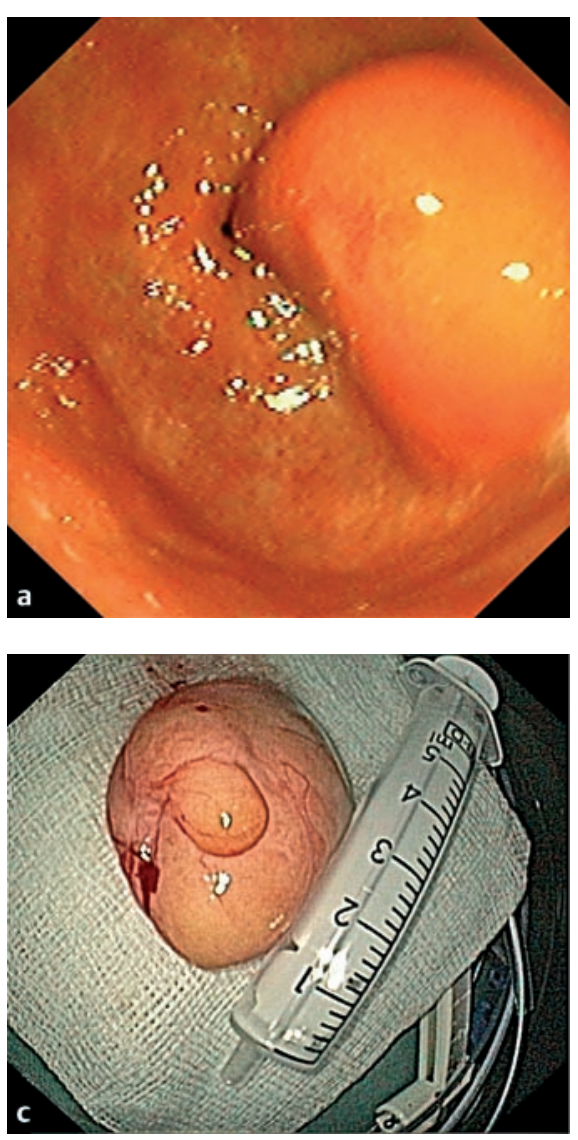
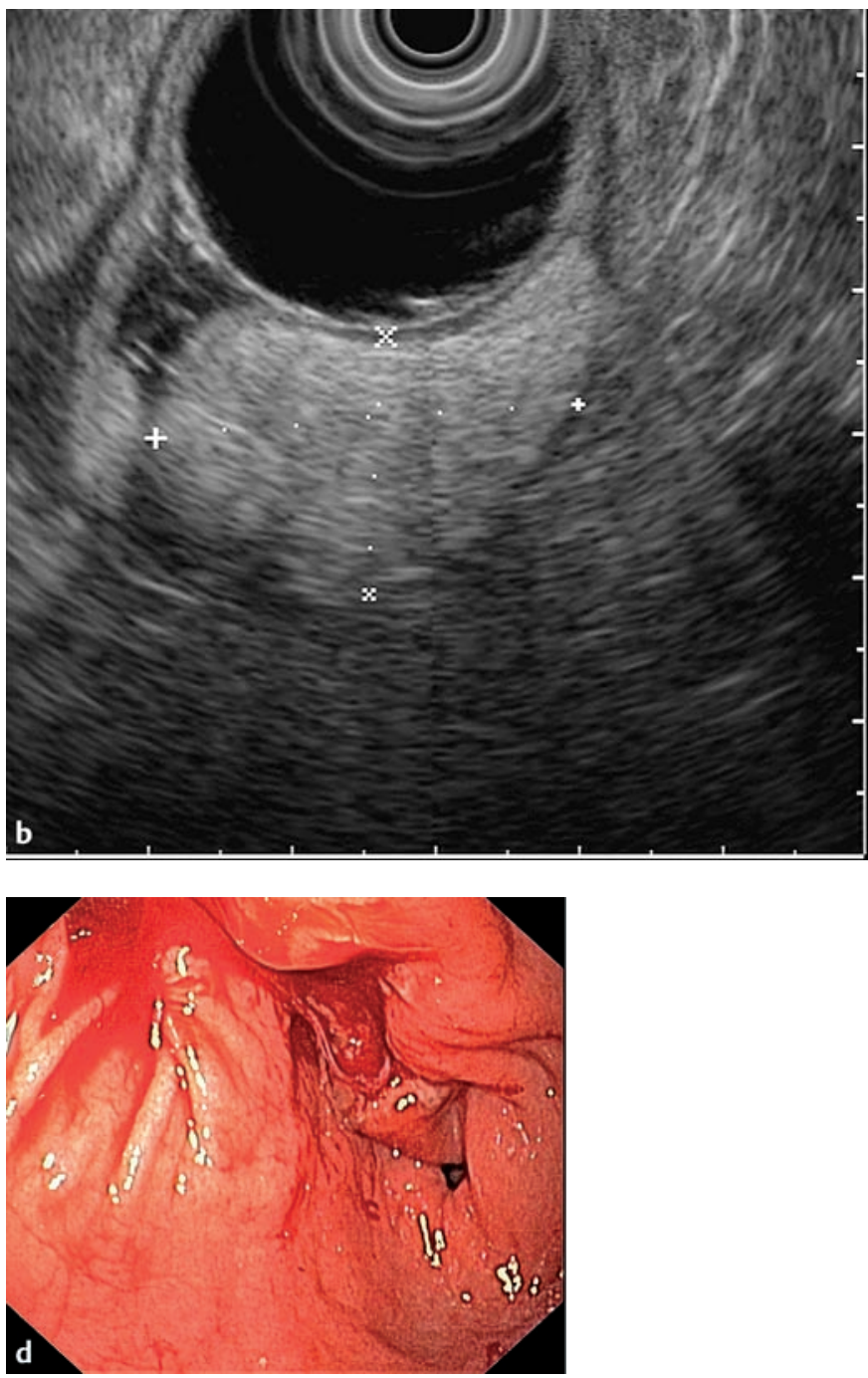

and a chest radiograph did not indicate any local complication such as (micro)perforation. Endoscopy suggested a large hernia with intermittent incarceration as a possible alternative source of the pain, but this remains speculative. One patient (H.G.) suffered a small microperforation with pain and fever for 2 days and small amounts of air in the mediastinum and neck; this healed under conservative treatment by means of nil per os, analgesics, and antibiotics. One patient (W.H.) with a history of stroke and sleep apnea syndrome developed pneumonia, probably due to aspiration; orally administered antibiotics led to complete recovery.

\section{Discussion}

The present pilot study focused on the technical efficacy of largearea mucosectomy and removal of SMTs using a newly developed insulated-tip knife. The study included a heterogeneous collection, from two centers, of upper gastrointestinal mucosal and submucosal lesions treated with the insulated-tip knife. The mucosal lesions included mainly classic upper gastrointestinal indications for mucosectomy, i.e., mucosal cancer, highgrade intraepithelial neoplasia, and adenoma. However, rarer indications for mucosectomy, such as total resection of metaplastic Barrett's mucosa or recurrent Barrett cancer following endother- apy were also included. Logically, the lesions selected for largearea mucosectomy were mainly larger lesions which would not have been expected to be resected in one piece by conventional cap mucosectomy.

In general, the effectiveness of EMR in curatively treating mucosal cancers of a certain size (up to $2 \mathrm{~cm}$ ) and histological nature is well established. Long-term studies have shown that, at least in well-differentiated upper gastrointestinal mucosal cancers, the results of EMR are similar to those reported from surgical series, with an overall 5-year disease-free survival of $99.5 \%$ [1]. In a nonrandomized Japanese study comparing 34 endoscopically treated and 44 operated cases with early esophageal cancer invading the mucosa or upper third of the submucosa, 5-year survival was only slightly better in the surgical group ( $85 \%$ vs. $77 \%$ ) [14].

However, in most of the studies the rates of en bloc resection of these cancers are still substantially limited. Oncological principles which have been applied in surgery for many decades, however, demand en bloc resection with adequate safety margins. In large Japanese and Western series, the rate of complete (R0) resection of mucosal cancers using the cap technique has been around $60-70 \%[1,5,15]$. As an example, in a recent Japanese paper including 106 cases of early gastric cancers up to $20 \mathrm{~mm}$ in 
Table 2 Overview of treatment efficacy in mucosal and submucosal lesions. Data are numbers of lesions

\begin{tabular}{|c|c|c|c|}
\hline \multicolumn{4}{|l|}{ Mucosal lesions } \\
\hline Total lesions & 24 & & \\
\hline Mucosectomy technically possible & 23 & & \\
\hline $\begin{array}{l}\text { Aim completely achieved, (i.e. in mucosal } \\
\text { lesion, en bloc EMR, R0 depth and lateral) }\end{array}$ & 6 & & \\
\hline Aim not achieved & 17 & & \\
\hline \multicolumn{4}{|l|}{ T1 lesion } \\
\hline R0, but piecemeal & (1) & & \\
\hline Rx, lateral/piecemeal & (4) & & \\
\hline $\mathrm{R} 1$, lateral & (5) & & \\
\hline R1, depth/lateral & (1) & & \\
\hline Rx, depth/lateral & (1) & & \\
\hline \multirow[t]{2}{*}{ T1sm lesion } & (4) & (R1, depth plus lateral & 2 \\
\hline & & $\mathrm{R} 1$, lateral & 2) \\
\hline \multicolumn{4}{|l|}{$\begin{array}{l}\text { Among } 17 \text { lesions for which aim was } \\
\text { not achieved: }\end{array}$} \\
\hline \multirow[t]{2}{*}{ En bloc EMR } & 7 & (R0, at follow-up & 5 \\
\hline & & Residual tumor & 2) \\
\hline \multirow[t]{2}{*}{ No tumor residues } & 9 & (Surgery & 5 \\
\hline & & Follow-up biopsy & 4) \\
\hline \multicolumn{4}{|l|}{ Submucosal lesions } \\
\hline Total lesions & 14 & & \\
\hline Removal technically possible & 14 & & \\
\hline $\begin{array}{l}\text { Aim completely achieved (i. e., tumor } \\
\text { resected en bloc, complete removal) }\end{array}$ & 5 & & \\
\hline Aim not achieved & 9 & & \\
\hline En bloc, complete removal uncertain & (2) & & \\
\hline Two pieces, but complete removal & (6) & & \\
\hline Two pieces, complete removal uncertain & & & \\
\hline
\end{tabular}

diameter, an $\mathrm{R} 0$ resection rate of $79 \%$, with a piecemeal resection rate of $36 \%$, was reported. In the short-term follow-up (mean 12 months), recurrence was $1.5 \%$ in the en bloc group vs. $5.3 \%$ in the piecemeal group [7]. In a mixed series from the USA, complete resection was achieved in $89 \%$ of lesions, with $17 \%$ requiring more than one session [6].

We are therefore convinced that in the long term we must strive for methods of mucosectomy of mucosal cancers and other lesions that are improved from an oncological standpoint, that is, they provide en bloc removal with adequate safety margins. The new accessories, mainly knives for submucosal dissection, are aimed at achieving resection of a sufficiently large piece of mucosa that harbors the entire lesion, so that adequate histopathological assessment of the tumor and the resection margins can be done. In the original publication by Ono et al., the insulated-tip knife was used in part of the study population. In the total patient group, complete resection was achieved in only $69 \%$ of cases overall, but results for the different techniques were not specified [8]. Another series that included 123 lesions in 120 patients with early cancer treated with the insulated-tip knife, showed an en bloc resection rate of only $54 \%$, with $41 \%$ of all specimens being $\mathrm{R} 0$ resections [12]. In another series of 70 gastric lesions where a conventional needle-knife was used for dissection, the rates of en bloc resection and complete R0 tumor removal were $76 \%$ and $77 \%$, respectively. In this series a different, longer-lasting solution was used for submucosal injection, namely hyaluronic acid [16].

The above results and those of our pilot series show that the likelihood of complete en bloc resection of mucosal lesions is probably improved by new techniques, but further technical refinements are still necessary, such as better injection solutions and use of a variety of accessories, and better endoscopes [10,11]. Our low success rate was also due to our strict definition of success (complete removal in one piece). We can also show that applying a more liberal definition of treatment success as used in most other series, i.e., complete removal in several pieces plus no tumor found on surgery or follow-up, would substantially improve our results. It is also noteworthy that $40 \%$ of our mucosal lesions were larger than $2 \mathrm{~cm}$. Reducing the time required for these procedures is another issue of great practical importance. Large-area mucosectomy should be restricted to expert centers which also offer all possible options for conservative, endoscopic, and surgical complication management..

The endoscopic resection of SMTs is clinically a separate issue, and many uncertainties still exist in this field. Despite the use of endoscopic and endosonographic examination, in many cases no definitive pretherapeutic diagnosis can be made concerning both the type or nature of the lesion and the determination of malignancy. Certainly, size and location play a crucial role, with lesions located in the esophagus and those up to $1 \mathrm{~cm}$ very rarely harboring malignancy. In the stomach, gastrointestinal stromal tumors (GIST) are not infrequent, as shown in our series, and their malignant potential is not fully known, especially that of smaller lesions [17]. Pretherapeutic determination of the tumor type and status is desirable, but the endoscopic and endosonographic possibilities for tissue acquisition are still limited and are controversial $[18,19]$.

Endoscopic resection of upper gastrointestinal SMTs, using different techniques, has been reported in a few papers. Some years ago, a group from Korea treated 62 patients with esophageal SMTs up to $7.5 \mathrm{~cm}$ in size. The smaller and well-circumscribed lesions were resected by conventional polypectomy, the larger and flatter ones by mucosal incision and enucleation using electrocautery snare electrodes. The complete resection rate in this study was $98 \%$, without major complications and no recurrence of the 61 lesions which had been completely resected. Histological examination showed 56 leiomyomas, four granular cell tumors, one neurogenic tumor, and one cyst [20]. Another series from Japan included 26 esophageal and 23 gastric lesions resected conventionally with a snare using a double-channel endoscope. Whereas none of the esophageal lesions was malignant, two of the 23 gastric lesions were, and both were small $(15 \mathrm{~mm}$ and $25 \mathrm{~mm}$ ); the GIST nomenclature was not used in this paper [21]. Finally, an EUS-based approach has also been presented: puncture echo endoscopes were used for monitoring saline injection underneath deep mucosal and submucosal lesions, and these were then resected endoscopically using a snare [22]. All these series are feasibility studies too, and, based on our experience of the difficulties in transecting the tumors completely from the base in one piece, we wonder whether complete resection had really been achieved in all cases. Long-term follow-up (mean 38 months) had only been carried out in one of the studies 
[20], and there is no mention of GIST tumors in any of these publications, which were still using the nomenclature from the preGIST era. Alternative methods such as laparoscopic or combined laparoscopic-endoscopic procedures must also be considered, but these necessarily require general anesthesia [23,24]. Further studies on endotherapy compared with laparoscopic surgery, as well as on the spontaneous long-term course of smaller SMTs, are necessary to arrive at a uniform management plan for these lesions.

In summary, endoscopic submucosal dissection of mucosal and submucosal neoplasms is still in a developmental stage. Success rates, if strictly defined as en bloc removal in one session, are too low with conventional cap techniques and have to be greatly improved. The technique of large-area resection of lesions using the insulated-tip knife is a step in the right direction. Further refinements of endoscopes and accessories will ultimately help to achieve the goal of en bloc resection with adequate safety margins.

\section{References}

${ }^{1}$ Kojima T, Parra-Blanco A, Takahashi $\mathrm{H}$ et al. Outcome of endoscopic mucosal resection for early gastric cancer: Review of the Japanese literature. Gastrointest Endosc 1988; 48: 550-554

2 Rembacken BJ, Gotoda T, Fujii T et al. Endoscopic mucosal resection. Endoscopy 2001; 33: 709- 718

${ }^{3}$ Tani M, Sakai P, Kondo H. Endoscopic muco resection of superficial cancer in the stomach using the cap technique. Endoscopy 2003; 35 : $348-355$

${ }^{4}$ May A, Gossner L, Pech O et al. Intraepithelial high-grade neoplasia and early adenocarcinoma in short-segment Barrett's esophagus (SSBE): curative treatment using local endoscopic treatment techniques. Endoscopy 2002; 34: 604-610

${ }^{5}$ Ell C, May A, Gossner L et al. Endoscopic mucosection of early cancer and high-grade dysplasia in Barrett's esophagus. Gastroenterology 2000; 118: 670-677

${ }^{6}$ Ahmad NA, Kochman ML, Long WB et al. Efficacy, safety, and clinical outcome of endoscopic mucosal resection: a study of 101 cases. Gastrointest Endosc 2002; 55: 390-396

${ }^{7}$ Tanabe S, Koizumi W, Mitomi H et al. Clinical outcome of endoscopic aspiration mucosectomy for early stage gastric cancer. Gastrointest Endosc 2002; 56: 708-713

${ }^{8}$ Ono H, Kondo H, Gotoda T et al. Endoscopic mucosal resection for treatment of early gastric cancer. Gut 2001; 48: 225 -229

${ }^{9}$ Oda I, Gotoda T, Hamanaka H et al. A novel endoscopic mucosal resection technique for early gastric cancer: submucosal dissection method with an insulation-tipped (IT) knife [abstract]. Endoscopy 2003; 35 Suppl II : A43-

${ }^{10}$ Yamamoto H, Kawata H, Sunada K et al. Successful en bloc resection of large superficial tumors in the stomach and colon using sodium hyaluronate and small-caliber-tip transparent hood. Endoscopy 2003; 35 : $690-694$

${ }^{11}$ Miyashita M, Tajiri T, Maruyama H et al. Endoscopic mucosal resection scissors for the treatment of early gastric cancer. Endoscopy 2003; 35 : $611-612$

${ }^{12}$ Miyamoto S, Muto M, Hamamoto Y et al. A new technique for endoscopic mucosal resection with an insulated-tip electrosurgical knife improves the completeness of resection of intramucosal gastric neoplasms. Gastrointest Endosc 2002; 55: 576 - 581

13 World Health Organization. Pathology and Genetics of Tumours of the Digestive System In: Hamilton SR, Aaltonen LA (eds). Classification of Tumours Lyon: IARC Press, 2000

${ }^{14}$ Shimizu Y, Tsukagoshi H, Fujita M et al. Long-term outcome after endoscopic mucosal resection in patients with esophageal squamous cell carcinoma invading the muscularis mucosae or deeper. Gastrointest Endosc 2002; 56: 387-390

${ }^{15}$ Waxman I, Saitoh Y. Clinical outcome of endoscopic mucosal resection for superficial GI lesions and the role of high-frequency US probe sonography in an American population. Gastrointest Endosc 2000; 52: $322-327$

${ }^{16}$ Yamamoto H, Kawata H, Sunada K et al. Success rate of curative endoscopic mucosal resection with circumferential mucosal incision assisted by submucosal injection of sodium hyaluronate. Gastrointest Endosc 2002; 56: $507-512$

${ }^{17}$ Chandu de Silva MV, Reid R. Gastrointestinal stromal tumors (GIST): C-kit mutations, CD117 expression, differential diagnosis and targeted cancer therapy with imatinib. Pathol Oncol Res 2003; 9: 13-19

${ }^{18}$ Ando N, Goto H, Niwa Y et al. The diagnosis of GI stromal tumors with EUS-guided fine needle aspiration with immunohistochemical analysis. Gastrointest Endosc 2002; 55: 37 - 43

${ }^{19}$ Hunt GC, Rader AE, Faigel DO. A comparison of features between CD117 positive GI stromal tumors and CD-117 negative spindle cell tumors. Gastrointest Endosc 2003; 57: 469-474

${ }^{20}$ Hyun JH, Jeen YT, Chun HJ et al. Endoscopic resection of submucosal tumor of the esophagus: results in 62 patients. Endoscopy 1997; 29: $165-170$

${ }^{21}$ Kojima T, Takahashi H, Parra-Blanco A et al. Diagnosis of submucosal tumor of the upper GI tract by endoscopic resection. Gastrointest Endosc 1999; 50: $516-522$

22 Sun S, Wang M. Use of endoscopic ultrasound-guided injection in endoscopic resection of solid submucosal tumors. Endoscopy 2002; 34 : $82-85$

${ }^{23}$ Ludwig K, Wilhelm L, Scharlau U et al. Laparoscopic-endoscopic rendezvous resection of gastric tumors. Surg Endosc 2002; 16: 1561 1565

${ }^{24}$ Walsh RM, Ponsky J, Brody F et al. Combined endoscopic/laparoscopic intragastric resection of gastric stromal tumors. J Gastrointest Surg 2003; 7: $386-392$ 